\title{
Numerical simulations to account for boulder movements on Lanyu Island, Taiwan: tsunami or storm?
}

\author{
Mamoru Nakamura*, Yasuhisa Arashiro and Shota Shiga
}

\begin{abstract}
Boulders that originated from the Holocene coral terrace and coral reef are distributed on the coral terrace or talus on the shore of Lanyu Island, Taiwan. We employed numerical simulation of storm waves and estimated whether the boulders could be moved by storm waves with a return period of 50 years, by larger storm waves with return periods of hundreds of years, or by tsunamis. The coral boulders are distributed between 36 and $128 \mathrm{~m}$ from the shoreline at elevations of 2.7 to $9.3 \mathrm{~m}$. The sizes of the boulders are in the range 0.3 to $6.4 \mathrm{~m}$. The boulder volume and $a$-axis length versus distance from the shore show weak and moderate correlation ( $r=0.21$ and 0.48$)$, respectively. We reproduced the runup of waves using the equation of continuity for a two-dimensional non-compressive fluid and the Navier-Stokes formula. In order to handle the free surface of the fluid, the volume of fluid method was applied. For the flow velocity to move the boulder, we employed the theoretical formula for the transport of boulders. We used the wave height for a return period of 50 years and set the height of the input wave to $13.1 \mathrm{~m}$. The results show that all the large boulders on Lanyu Island could be moved by storm waves with a return period of 50 years. Moreover, the computations show that most of the boulders could not have been transported by tsunamis generated by the Mw8.7 earthquakes. The ages of two boulders indicate that they were transported after 340 and 6,330 years ago. If these boulders were moved by tsunamis several hundred years ago, they would have been relocated subsequently by storm waves.
\end{abstract}

Keywords: Tsunami boulders; Boulder transport; Storm; Taiwan; Lanyu Island

\section{Background}

Analysis of past tsunami sediments is one of the most important tools for past tsunami reconstruction. The identification of a tsunami deposit is often based on the identification of anomalous sand deposits found in peat or mud that was deposited in low-energy environments such as coastal ponds, lakes, and marshes.

Boulders are an indicator of high-energy events such as tsunamis or storms (e.g., Simkin and Fiske 1983; Harmelin-Vivien and Laboute 1986; Goff et al. 2006; Goto et al. 2009, 2010a, b; Mastronuzzi and Pignatelli 2012). Boulders of Holocene coral limestone that had been transported by tsunamis were distributed on the beach and land areas of the south Ryukyu Islands (Kawana and Nakata 1994; Goto et al. 2010b). Based on dating of

\footnotetext{
* Correspondence: mnaka@sci.u-ryukyu.ac.jp

Faculty of Science, University of the Ryukyus, 1 Senbaru, Nishihara-cho, Nakagami-gun, Okinawa 903-0213, Japan
}

fossil coral on the boulders, the historical occurrences of several huge tsunamis were estimated on the south Ryukyu Islands (Kawana and Nakata 1994; Goto et al. 2010b; Araoka et al. 2013).

A coral reef surrounds the Ryukyu Islands. Storm waves are broken by the reef, and the extreme level of wave energy capable of moving boulders is limited to within $200 \mathrm{~m}$ of the reef crest because of the short wavelength of storm waves (Goto et al. 2009). As the width of the reef lagoon is 1,000 to $2,000 \mathrm{~m}$ in the south Ryukyu Islands, storm waves that are broken at the reef crest cannot reach shore. However, as the width of the reef lagoon is narrower than the typical tsunami wavelength (which is at least several tens of kilometers), tsunami waves could traverse the lagoon to reach the beach. The computed runup height of a tsunami with a reef width of $1,000 \mathrm{~m}$ is about half the runup height without a reef (Kunkel et al. 2006). Using the difference of wave energy distribution 
between storms and tsunamis, we can distinguish tsunami boulders from boulders in the reef lagoon area (Goto et al. 2010a, b).

Eastern Taiwan is a typical convergent plate boundary, where the Luzon Arc on the Philippine Sea plate is colliding with the Eurasian continental margin (Figure 1). Global Positioning System (GPS) observations indicate that the Philippine Sea plate is moving to the northwest at a rate of about $88 \mathrm{~mm} /$ year relative to the Chinese continental margin (Yu et al. 1997). Active faults are distributed both in the Taiwan Island area and in the offshore area to the east of Taiwan (Shyu et al. 2005); the most active type of fault in the offshore area is the reverse fault.

The western extension of the Ryukyu subduction zone terminates in the northeastern Taiwan region. A historical tsunami occurred in 1771 along the southwestern Ryukyu Trench (Nakamura 2009; Goto et al. 2010b). The wide interplate coupling area has been estimated in the southwestern Ryukyu Trench from GPS measurements (Hsu et al. 2012). Hsu et al. (2012) compared the computed surface deformation obtained using the interplate coupling model with the observed surface deformation by GPS and noted that interplate earthquakes with magnitudes of 7.5 to 8.7 would occur in the southwestern Ryukyu Trench. Traces of at least three paleo-tsunamis have been reported from the east of Taiwan (Matta et al. 2010; Ota 2013). However, the source faults and the magnitudes of the earthquakes are not known.

Here, we focus on Lanyu Island for the investigation of tsunamis. Lanyu Island is located about $90 \mathrm{~km}$ southeast of Taiwan (Figure 1). It is underlain by andesitic rocks ranging from 3.5 to $1.4 \mathrm{Ma}$ (Yang et al. 1995, 1996) and is surrounded by coral reef terraces at several elevations from mean sea level that developed from the Pleistocene to the Holocene (Chen and Liu 1992). The lower uplifted coral reefs occur at heights of up to $4 \mathrm{~m}$ above mean sea level and encircle almost the entire coastline. Talus deposits are distributed across almost the entire coastline (Inoue et al. 2011). The lagoons of the coral reef are not well developed around Lanyu Island. The distance from the shoreline to the reef crest is only about $30 \mathrm{~m}$. Boulders of coral are distributed along the shoreline of Lanyu Island. The largest boulder is $6.4 \mathrm{~m}$ and is located about $66 \mathrm{~m}$ from the shore on the north coast of the island (Figure 2).

Boulders studded along the shore suggest that historically large tsunamis or large storm waves have struck Lanyu Island, although no historical tsunamis have been reported. However, the boulders might have been transported not by tsunamis, but by storm waves. Therefore, in this paper, we reproduce storm waves using numerical

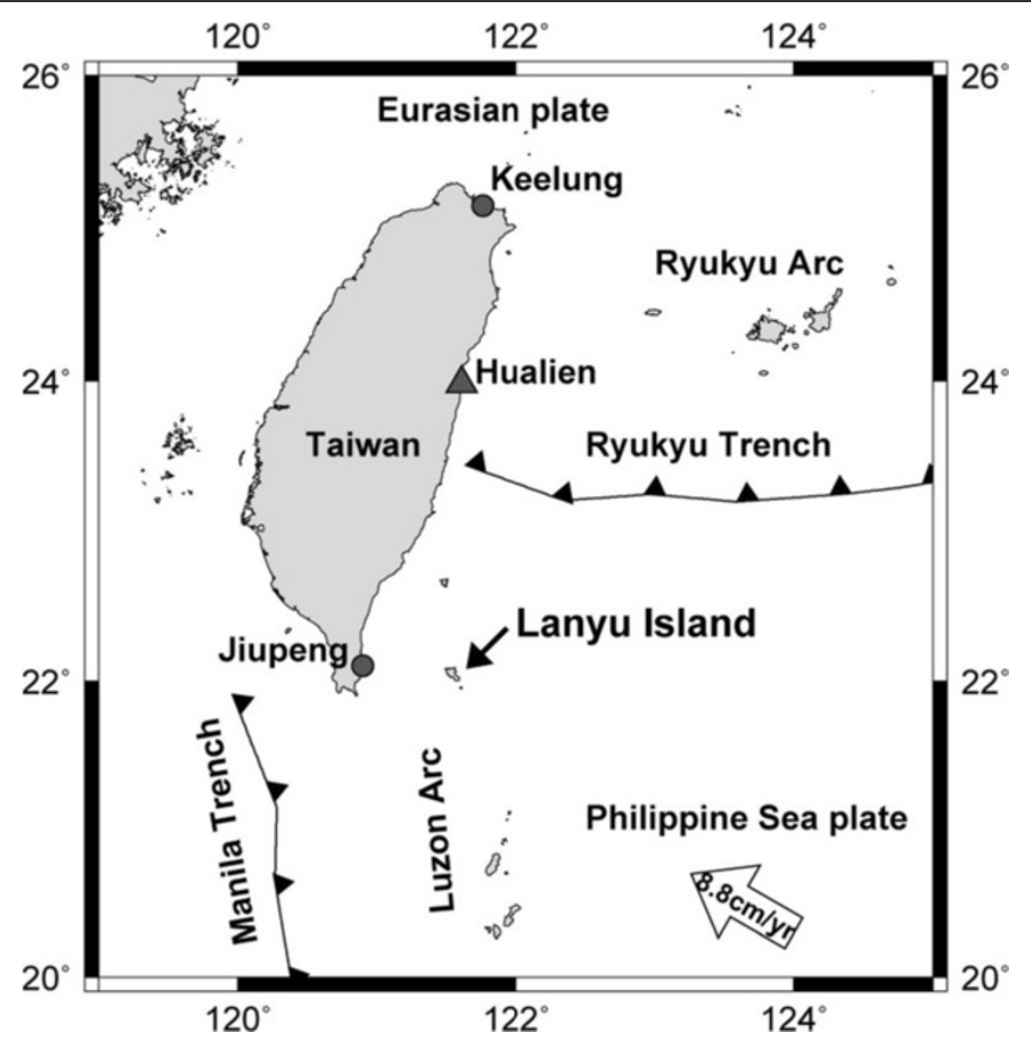

Figure 1 Map of Taiwan and Lanyu Island. 


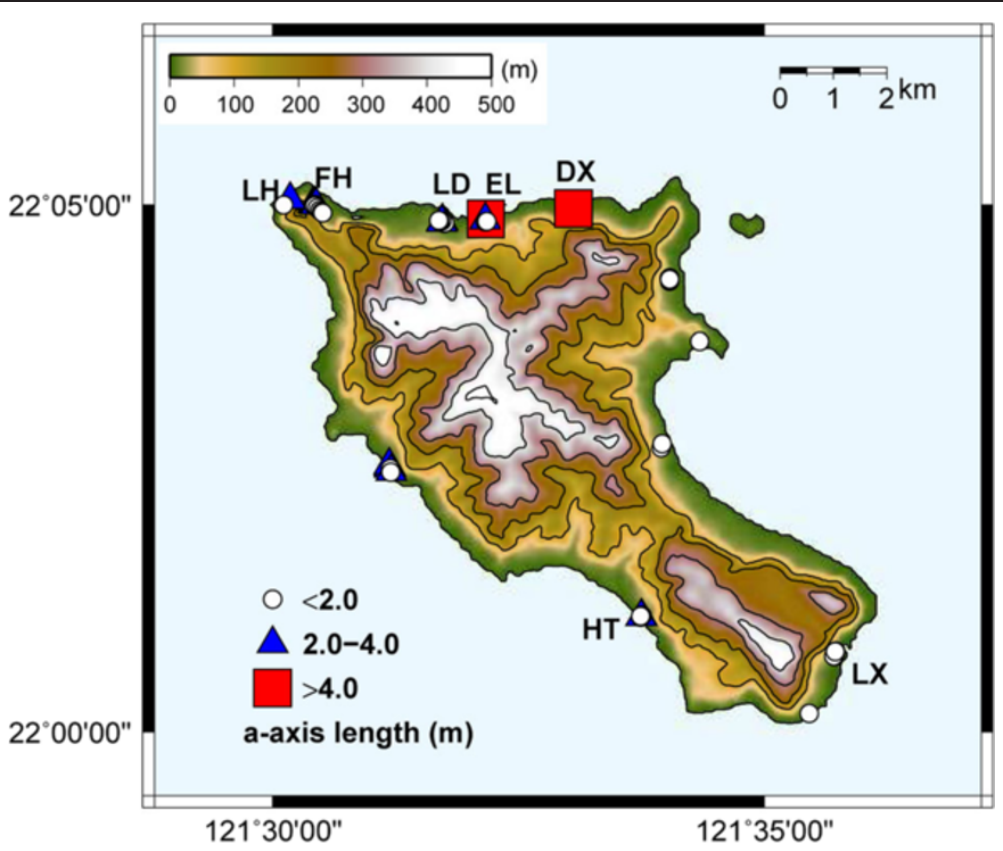

Figure 2 Distributions of boulders on Lanyu Island. HT, Hongtou; DX, Dong-Xi; EL, East of Langdao; LD, Langdao; FH, Five-Hole Cave; LH, Lighthouse; LX, Longmen-Xi. Contours at 100-m intervals. Circles, triangles, and squares show the sizes of the boulders with an $a$-axis length of $<2,2$ to 4 , and $>4 \mathrm{~m}$, respectively.

simulation and clarify whether the boulders could have been transported by storm waves.

\section{Regional setting}

\section{Historical tsunamis in Taiwan}

Historically, in Taiwan, 18 tsunamis are reported to have struck the east of the island. The most destructive tsunami in Taiwan occurred on December 18, 1867, and affected the area of Keelung in northern Taiwan. The maximum tsunami height was $7.5 \mathrm{~m}$ at Keelung, and this tsunami left hundreds of people dead (Ma and Lee 1997; Mak and Chan 2007; Lau et al. 2010). In contrast, the heights of other historical tsunamis were about $1 \mathrm{~m}$ or less. The city most frequently affected by valid tsunamis is Hualien in eastern Taiwan, which has recorded nine events since 1951. However, these tsunamis were not particularly fatal or disastrous: they were all minor tsunamis detected by tidal gauges.

Additional evidence of historical and/or prehistorical tsunamis in Taiwan is provided by tsunami boulders. Coral boulders are distributed within 30.0 to $76.5 \mathrm{~m}$ of the shoreline on the Jiupeng coast of southeastern Taiwan (Matta et al. 2013) (Figure 1). The fossil ages of samples taken from the outer parts of the coral boulders are 4,570 to 5,490 calendar (Cal) years $\mathrm{BP}$, similar to the ages of the underlying Holocene coral terrace (Matta et al. 2013). It is supposed that the coral boulders originated from the Holocene coral terrace and were broken and transported landward by tsunami waves striking the marine terrace.
However, it is impossible to estimate the dates of the associated tsunamis.

Historical tsunamis on Lanyu Island have not been documented in the literature before 1950. The folklore of Lanyu Island states that 'After an unusually low tide followed by a big wave, and the island was completely inundated. Goats, pigs, and chickens were killed by the inundation, and people on the island starved and died.' (Asai and Ogawa 1935).

Small tsunamis have been recorded by the tidal gauge on Lanyu Island since 1950. Two tsunamis with heights of $0.1 \mathrm{~m}$ were observed on Lanyu Island, caused by events on July 23, $1978\left(22.19^{\circ} \mathrm{N}, 121.42^{\circ} \mathrm{E}\right.$; depth: $26 \mathrm{~km}$; Mw 7.0) and May 4, $1998\left(22.43^{\circ} \mathrm{N}, 125.37^{\circ} \mathrm{E}\right.$; depth: $24 \mathrm{~km}$; Mw 7.5) (Lau et al. 2010).

\section{Typhoons in eastern Taiwan}

The shores of eastern Taiwan often receive high storm waves that have been generated by typhoons. Table 1 presents the annual maximum significant wave heights, period, and direction for a 19-year period (1990 to 2008) in Hualien (Figure 1) (Su et al. 2009). This wave analysis was obtained from buoy data used to derive directional wave height and period information in the area offshore of the port in Hualien.

The annual maximum significant wave height for the period ranges from 3.5 to $10.8 \mathrm{~m}$, with an average annual maximum significant wave height of $7.5 \mathrm{~m}$. The dominant wave period ranges from 6 to $14 \mathrm{~s}$, with an average 
Table 1 Annual maximum $\mathrm{Hs}$ and $\mathrm{Tp}$ and direction for Hualien during 1990 to 2008 (Su et al. 2009)

\begin{tabular}{|c|c|c|c|c|c|}
\hline & Hs (m) & $\mathrm{Tp}(\mathrm{s})$ & Direction & Year & Month/day \\
\hline & 10.2 & 14 & * & 1990 & $6 / 23$ \\
\hline & 9.9 & 13 & $*$ & 1991 & $7 / 19$ \\
\hline & 6.9 & 13 & * & 1992 & $9 / 22$ \\
\hline & 5.6 & 14 & * & 1993 & $6 / 26$ \\
\hline & 10.5 & 14 & * & 1994 & $7 / 10$ \\
\hline & 6.8 & 13 & * & 1995 & $8 / 30$ \\
\hline & 7.5 & 13 & * & 1996 & $7 / 31$ \\
\hline & 8.9 & 14 & * & 1997 & $8 / 28$ \\
\hline & 7.4 & 13 & * & 1998 & $10 / 16$ \\
\hline & 3.5 & 10 & * & 1999 & $12 / 20$ \\
\hline & 8.9 & 14 & * & 2000 & $8 / 22$ \\
\hline & 5.8 & 8 & SSE & 2001 & $7 / 4$ \\
\hline & 8.2 & 6 & ENE & 2002 & $7 / 3$ \\
\hline & 3.8 & 6 & SE & 2003 & $4 / 24$ \\
\hline & 5.7 & 9 & SE & 2004 & $10 / 19$ \\
\hline & 10.8 & 12 & ESE & 2005 & $10 / 2$ \\
\hline & 5.3 & 8 & SE & 2006 & $7 / 14$ \\
\hline & 9.3 & 12 & NNE & 2007 & $8 / 18$ \\
\hline & 7.3 & 12 & ESE & 2008 & $7 / 28$ \\
\hline Max & 10.8 & 14 & & & \\
\hline Min & 3.5 & 6 & & & \\
\hline Average & 7.5 & 12 & & & \\
\hline
\end{tabular}

Asterisks denote no data. $\mathrm{Hs}$, significant wave height; $\mathrm{Tp}$, associated period.

dominant period of $12 \mathrm{~s}$. The predominant wave direction is easterly. The maximum significant wave height during the 19-year period was generated by Typhoon Longwang on October 2, 2005 (significant wave height = $10.8 \mathrm{~m}$, associated period $=12 \mathrm{~s}$, direction $=\mathrm{ESE}$ ). Typhoon Longwang passed Hualien as a category 4-equivalent.

The significant wave heights for the 50- and 100-year periods were estimated using the observed significant wave heights from the 19-year data set from Hualien. The estimated significant wave height is 13.1 and $14.0 \mathrm{~m}$ for the 50 - and 100 -year probability, respectively (Jiang et al. 2011).

\section{Methods}

\section{Measurements of topography and boulders}

Field surveys on Lanyu Island were performed from $\mathrm{Au}$ gust 31 to September 4, 2012, and from August 30 to September 5, 2013. Along selected survey lines oriented perpendicular to the coastline and starting from the shoreline, cross sections were obtained using azimuth, distance, and elevation measurements taken with a TruPulse
360 laser range finder (Laser Technology, Inc., Centennial, Co, USA). Elevation was measured relative to sea level along each line during the survey and converted to elevation relative to mean sea level. The survey line lengths were almost $200 \mathrm{~m}$.

The positions of the coral boulders were measured by handheld GPS. The dimensions ( $\mathrm{a}-, \mathrm{b}-$, and $c$-axis) of the boulders were measured in the field by approximating the boulder shape as a rectangular parallelepiped. Here, the $a-, b$-, and $c$-axes are defined as the long, intermediate, and short axes of the boulder, respectively (Nott 2003). Radiocarbon dating was performed for two boulders at Langdao (LD) and Longmen-Xi (LX).

\section{Estimation of minimum flow velocity}

When flow velocity increases, boulders are transported by sliding, rolling, and saltation (Nott 2003; Nandasena et al. 2011). The magnitude of the flow velocity required to initiate movement of the boulder depends on the size of the boulder, its density, and the angle of the bed slope. To estimate the flow velocities required to move the boulders, we employed the formula of Nandasena et al. (2011).

The hydrodynamic equations by Nandasena et al. (2011) follows.

For sliding:

$$
u^{2} \geq \frac{2\left(\rho_{\mathrm{s}} / \rho_{\mathrm{w}}-1\right) g c\left(\mu_{\mathrm{s}} \cos \theta+\sin \theta\right)}{C_{\mathrm{d}}(c / b)+\mu_{\mathrm{s}} C_{\mathrm{l}}}
$$

For rolling or overturning:

$$
u^{2} \geq \frac{2\left(\rho_{\mathrm{s}} / \rho_{\mathrm{w}}-1\right) g c\left(\mu_{\mathrm{s}} \cos \theta+(c / b) \sin \theta\right)}{C_{\mathrm{d}}\left(c^{2} / b^{2}\right)+C_{\mathrm{l}}}
$$

For saltation:

$$
u^{2} \geq \frac{2\left(\rho_{\mathrm{s}} / \rho_{\mathrm{w}}-1\right) g c \cos \theta}{C_{\mathrm{l}}}
$$

where $\rho_{\mathrm{w}}$ and $\rho_{\mathrm{s}}$ represent the density of the water and boulder, respectively; $a, b$, and $c$ are the long, intermediate, and short axes of the boulder, respectively; $C_{\mathrm{d}}$ and $C_{1}$ are the coefficient of drag and coefficient of lift, respectively; $\theta$ is the angle of the slope bed; and $g$ is the gravitational acceleration. The boulder is isolated, detached, and not buttressed, and the depth of water flow is higher than the height of the boulder and the flow velocity is depth averaged.

In the work of Nott (2003), the equations of initial flow velocity for submerged boulders and subaerial boulders were different. However, Nandasena et al. (2011) identified formularization problems for the subaerial case of Nott (2003), and they showed that the equations for both submerged boulders and subaerial boulders are the same (Equation 10 in Nandasena et al. (2011)). 
Therefore, we estimated the initial flow velocity without classifying the boulders as either submerged or subaerial. Moreover, the equations by Nandasena et al. (2011) exclude the inertia force because the effect of the inertia force would be small compared to that of the drag force.

The densities of the seawater and boulder were taken as 1,020 and $2,000 \mathrm{~kg} / \mathrm{m}^{3}$, respectively. The coefficient of drag and coefficient of lift were set to 1.95 and 0.178 , respectively (Nandasena et al. 2011), and the angle of the bed slope was set to $3^{\circ}$.

\section{Reproduction of boulder transport using numerical simulation}

We reproduced the runup of the waves using the CADMAS-SURF (SUper Roller Flume for Computer Aided Design of MAritime Structure) code (Coastal Development Institute of Technology 2001). This code is based on the equations of continuity for a two-dimensional non-compressive fluid and the Navier-Stokes formula:

$$
\begin{aligned}
& \frac{\partial \gamma_{x} u}{\partial x}+\frac{\partial \gamma_{z} w}{\partial z}=0 \\
& \lambda_{v} \frac{\partial u}{\partial t}+\frac{\partial \lambda_{x} u u}{\partial x}+\frac{\partial \lambda_{z} w u}{\partial z}=-\frac{\gamma_{v}}{\rho} \frac{\partial p}{\partial x}+\frac{\partial}{\partial x}\left\{\gamma_{x} v_{e}\left(2 \frac{\partial u}{\partial x}\right)\right\} \\
&+\frac{\partial}{\partial z}\left\{\gamma_{z} v_{e}\left(\frac{\partial u}{\partial z}+\frac{\partial w}{\partial x}\right)\right\}-R_{x} \\
& \lambda_{v} \frac{\partial w}{\partial t}+\frac{\partial \lambda_{x} u w}{\partial x}+\frac{\partial \lambda_{z} w w}{\partial z}=-\frac{\gamma_{v}}{\rho} \frac{\partial p}{\partial z}+\frac{\partial}{\partial z}\left\{\gamma_{x} v_{e}\left(\frac{\partial w}{\partial x}+\frac{\partial u}{\partial z}\right)\right\} \\
&+\frac{\partial}{\partial z}\left\{\gamma_{z} v_{e}\left(2 \frac{\partial w}{\partial z}\right)\right\}-R_{z}-\gamma_{v} g
\end{aligned}
$$

where $t$ is the time; $x$ and $z$ are the horizontal and vertical coordinates, respectively; $u$ and $w$ are the horizontal and vertical velocities, respectively; $v_{e}$ is the molecular kinematic viscosity; $\gamma_{v}$ is the porosity; $\gamma_{x}$ and $\gamma_{z}$ are the horizontal and vertical sectional transform ratios, respectively; $p$ is the pressure; $\rho$ is the mass density of the fluid; and $g$ is the acceleration due to gravity.

The coefficients of $\lambda_{v}, \lambda_{x}$, and $\lambda_{z}$ are:

$$
\begin{aligned}
& \lambda_{v}=\gamma_{v}+\left(1-\gamma_{v}\right) C_{\mathrm{M}}, \\
& \lambda_{x}=\gamma_{x}+\left(1-\gamma_{x}\right) C_{\mathrm{M}}, \\
& \lambda_{z}=\gamma_{z}+\left(1-\gamma_{z}\right) C_{\mathrm{M}},
\end{aligned}
$$

where $C_{\mathrm{M}}$ is the coefficient of inertia.

The horizontal and vertical drag forces $R_{x}$ and $R_{z}$ are as follows:

$$
\begin{aligned}
& R_{x}=\frac{1}{2} \frac{C_{\mathrm{D}}}{\Delta x}\left(1-\gamma_{x}\right) u \sqrt{u^{2}+w^{2}}, \\
& R_{z}=\frac{1}{2} \frac{C_{\mathrm{D}}}{\Delta z}\left(1-\gamma_{z}\right) w \sqrt{u^{2}+w^{2}},
\end{aligned}
$$

where $C_{\mathrm{D}}$ is the drag coefficient, and $\Delta_{x}$ and $\Delta_{z}$ are the horizontal and vertical mesh sizes for the numerical simulations, respectively. The coefficients of drag force and inertia are set as $C_{\mathrm{D}}=1.0$ and $C_{\mathrm{M}}=1.2$, respectively, by following Sakakiyama and Imai (1996).

In order to handle the free surface of the fluid, the volume of fluid (VOF) method (Hirt and Nichols 1981) was applied. The transfer diffusion equation $F$ of the VOF function is:

$$
\gamma_{v} \frac{\partial F}{\partial t}+\frac{\partial \gamma_{x} u F}{\partial x}+\frac{\partial \gamma_{z} w F}{\partial z}=0
$$

In this method, the advection equation of the VOF was solved using the donor-acceptor approach.

The input data of the CADMAS-SURF we used were significant wave height and its period, and topography. Output data of that were the wave height and velocity at any place and time. The marine and land areas for the horizontal calculation were set to 300 and $200 \mathrm{~m}$, respectively (Figure 3 ). The vertical calculation area was set to $80 \mathrm{~m}$.

In the numerical simulations, the horizontal and vertical mesh sizes of the marine area were set to 1.0 and $0.5 \mathrm{~m}$, respectively. The horizontal and vertical mesh

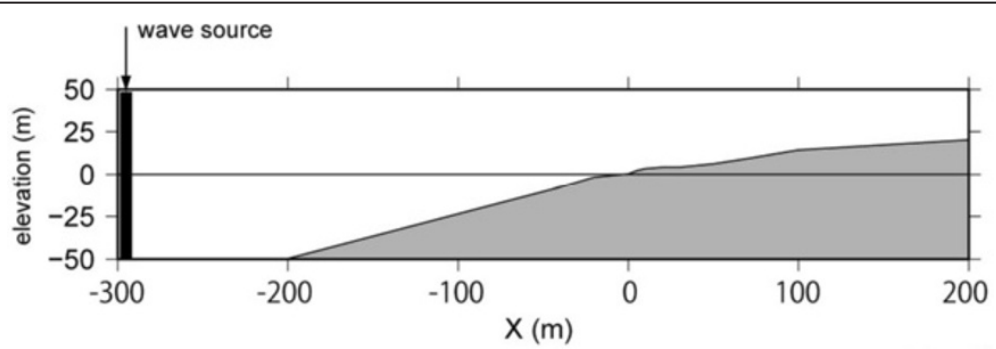

Figure 3 Diagram of vertical cross section of bathymetry and topography used in the numerical simulation. 
sizes at the land area were set to 0.5 and $0.25 \mathrm{~m}$, respectively. The time interval used in the simulations was calculated automatically based on the Courant-Friedrichs-Lewy condition.

We used the bottom friction law for rough surfaces:

$$
\frac{u_{t}}{u^{*}}=\frac{1}{0.4} \log \left[\frac{y}{k_{s}}\right]+8.5
$$

where $u_{t}$ and $u^{*}$ are the horizontal velocity and friction velocity, respectively; $y$ is the distance from the surface; and $k_{s}$ is the roughness of the surface. The value of $k_{s}$ is set to 1.0. This value corresponds to friction of $0.04 \mathrm{~m}^{-1 / 3}$ $\mathrm{s}$ in Manning's parameter $(n)$, which is obtained using the approximate formula (Nezu 1995):

$$
n \approx \frac{1}{24} k_{s}^{1 / 6}
$$

The reef (whose width and depth are 30 and $6 \mathrm{~m}$, respectively) was set for the marine bathymetry (Inoue et al. 2011). The topography of the land area was defined based on the results of topography surveys, and we used a fifth-order Stokes wave for the source function.

As a test of the numerical simulation, we calculated the runup of the storm waves at Hongtou $(\mathrm{HT})$ by the 2012 typhoon Tembin (Figure 2), which is located in the southwest of Lanyu Island. A maximum runup height of $11.4 \mathrm{~m}$ was observed for the 2012 typhoon Tembin. Based on the Grid Point Value coastal wave model of the Japan Meteorological Agency (Global Atmospheric Observation Data 2013), we estimated the significant wave height for Lanyu Island when the typhoon was approaching the island. This height was $2 \mathrm{~m}$ on August 26 but increased to over $4 \mathrm{~m}$ on August 27. The significant wave height reached a maximum of $6.6 \mathrm{~m}$ at 18:00 (UT) on August 28 (Figure 4). For the numerical simulation

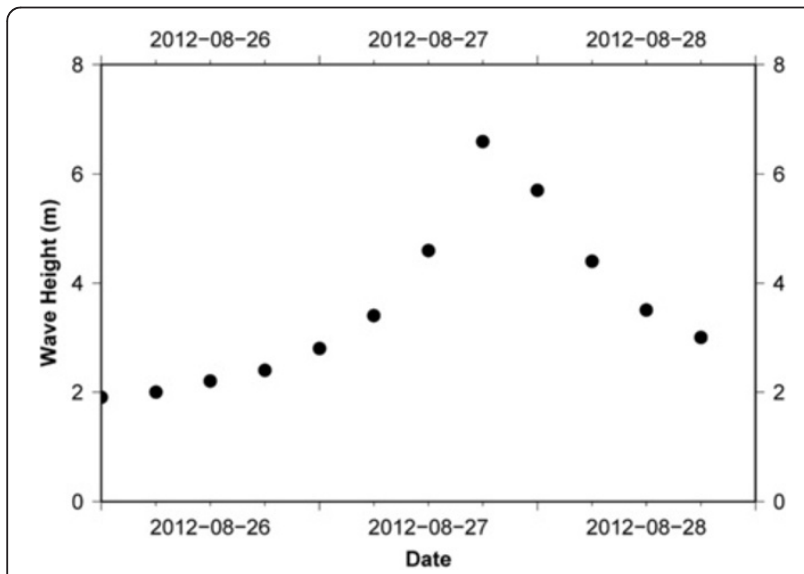

Figure 4 Significant wave heights off southwest Lanyu Island $\left(22^{\circ} 00^{\prime} \mathrm{N}, 121^{\circ} 28^{\prime} \mathrm{E}\right)$. Times are in UT. of the waves of the 2012 typhoon Tembin, we employed a wave height of $6.6 \mathrm{~m}$ and a corresponding period of $12.0 \mathrm{~s}$.

Then, we computed the runup of waves by adopting the wave height for the 50-year return period to estimate the movement of boulders in other areas. The significant wave heights at Hualien port for the 50- and 100-year return periods are 13.1 and $14.0 \mathrm{~m}$, respectively (Jiang et al. 2011). We employed the wave height for the 50-year return period and set the height of the input wave to $13.1 \mathrm{~m}$. Then, we computed the numerical simulation for two different wave periods of 12.0 and $14.0 \mathrm{~s}$, which were based on the observed wave periods corresponding to the annual maximum wave height at Hualien port.

Then, we computed a numerical simulation of a tsunami to compare the flow depth and flow velocity caused by a tsunami with those caused by storm waves. For the computation of the tsunami, the nonlinear long wave equations are used as follows:

$$
\begin{aligned}
& \frac{\partial \eta}{\partial t}+\frac{\partial Q_{x}}{\partial x}+\frac{\partial Q_{y}}{\partial y}=0 \\
& \frac{\partial Q_{x}}{\partial t}+\frac{\partial}{\partial x}\left[\frac{Q_{x}^{2}}{D}\right]+\frac{\partial}{\partial y}\left[\frac{Q_{x} Q_{y}}{D}\right] \\
& \quad+g D \frac{\partial \eta}{\partial x}+\frac{g n^{2}}{D^{7 / 3}} Q_{x}\left(Q_{x}^{2}+Q_{y}^{2}\right)^{1 / 2}=0 \\
& \frac{\partial Q_{y}}{\partial t}+\frac{\partial}{\partial x}\left[\frac{Q_{x} Q_{y}}{D}\right]+\frac{\partial}{\partial y}\left[\frac{Q_{y}^{2}}{D}\right]+g D \frac{\partial \eta}{\partial y} \\
& +\frac{g n^{2}}{D^{7 / 3}} Q_{y}\left(Q_{x}^{2}+Q_{y}^{2}\right)^{1 / 2}=0
\end{aligned}
$$

where $Q_{x}$ and $Q_{y}$ are discharge fluxes in the $x$ and $y$ directions, respectively; $\eta$ is the water surface elevation; and $D$ is the total water depth.

In the simulations of tsunami propagation, three grid sizes were adopted. The first, second, and third grids had 270, 90, and 30 grid sizes downsized from the 30arc-sec grid data provided by GEBCO (General Bathymetric Chart of the Oceans 2010), which covers the area $21.0^{\circ}$ to $24.8^{\circ} \mathrm{N}, 120.7^{\circ}$ to $125.6^{\circ} \mathrm{E}$ (Figure 5). The second (90-m grid) and third (30-m grid) areas encompassed $32 \times 32$ and $13.5 \times 13.5 \mathrm{~km}^{2}$ covering Lanyu Island. For the second and third areas, the 500-m grid data from GEBCO, an administration district map of Lanyu Island published by the Ministry of the Interior, Taiwan (Ministry of the Interior 2004), and topography data from the Shuttle Radar Topography Mission (2001) were used. We used a 0.25 -s time step for the $270-\mathrm{m}$ grid and a 0.08 -s time step for the 90 - and 30 -m grids. The total 


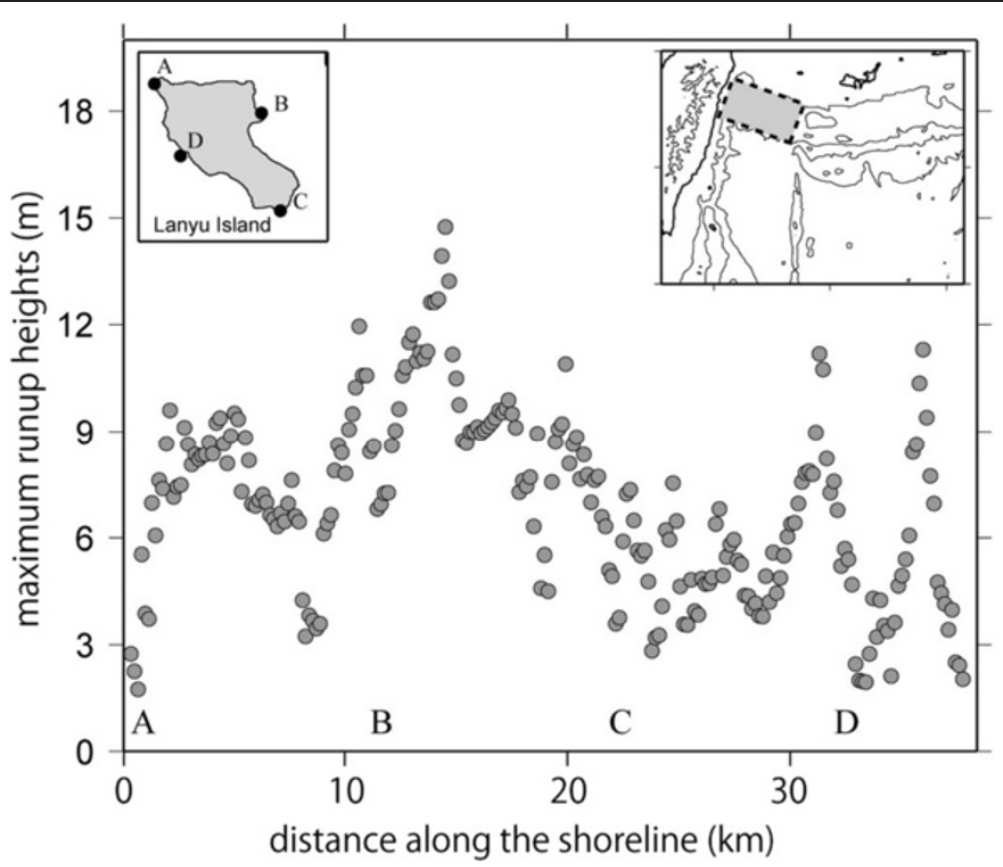

Figure 5 Computed runup heights of tsunami along the shore of Lanyu Island by Mw8.7 earthquake. The horizontal axis shows the distance along the shoreline from point A. The inserted figure at the top right shows the numerical simulation area and the tsunami sources used in this study (rectangle).

calculation time was $3 \mathrm{~h}$ after the earthquake's occurrence. For the Mw8.7 source fault model of Hsu et al. (2012), we employed the fault model of Ando et al. (2013) with values of fault length, width, strike, and dip of $130 \mathrm{~km}, 70 \mathrm{~km}, 290^{\circ}$, and $10^{\circ}$, respectively. The slip of the fault was set at $46 \mathrm{~m}$. The rake of the slip was $155^{\circ}$, which indicates a reverse-type fault with a large strike-slip component. Rigidity was set to $40 \mathrm{GPa}$.

\section{Results}

\section{Size distribution of boulders}

We measured 63 coral boulders around Lanyu Island. The boulders were distributed between 36 and $128 \mathrm{~m}$ from the shoreline (Figure 6), and their elevations ranged from 2.4 to $9.3 \mathrm{~m}$. The sizes of the boulders ranged from 0.3 to $6.4 \mathrm{~m}$.

The size distribution of the boulders exhibited a landwardfining trend: larger boulders were distributed near the shore and smaller boulders were distributed further inland. Plots of boulder volume and $a$-axis length versus distance from the shore exhibit weak and moderate correlation (correlation coefficient: $r=0.21$ and 0.48 ), respectively.

Table 2 shows the velocity for each transport mode (sliding, rolling, and saltation), estimated from the size of the boulders. The boulder transport histogram shows that the flow velocities required for sliding, rolling, and saltation are 1.4 to $5.1,1.6$ to 7.3 , and 5.7 to $16.9 \mathrm{~m} / \mathrm{s}$, respectively. Table 3 shows the computed flow depth and flow velocity at the position of boulders caused by waves with a return period of 19,50 , and 100 years, respectively. The flow depth and flow velocity are 0.2 to $5.9 \mathrm{~m}$ and 0.2 to $10.3 \mathrm{~m} / \mathrm{s}$ for a return period of 19 years but increase to 2.9 to $10.0 \mathrm{~m}$ and 5.0 to $13.7 \mathrm{~m} / \mathrm{s}$ for a return period of 100 years.

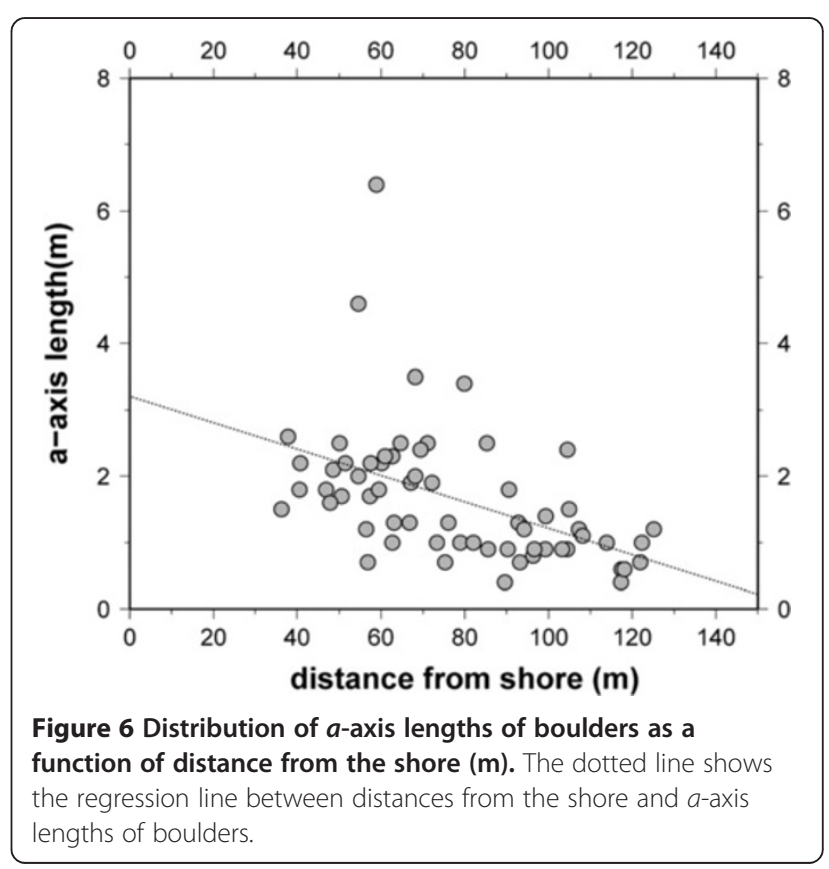


Table 2 Parameters of boulders in the areas where the numerical simulations were employed

\begin{tabular}{|c|c|c|c|c|c|c|c|c|c|}
\hline ID & Location & Distance from the shore $(\mathrm{m})$ & Elevations (m) & $a$-axis (m) & $b$-axis (m) & $c$-axis $(\mathrm{m})$ & Sliding $(\mathrm{m} / \mathrm{s})$ & Rolling (m/s) & Saltation $(\mathrm{m} / \mathrm{s})$ \\
\hline 1 & HT & 75.3 & 8.8 & 0.7 & 0.5 & 0.3 & 1.8 & 2.6 & 5.7 \\
\hline 2 & HT & 73.4 & 9.1 & 1.0 & 0.7 & 0.3 & 2.0 & 3.1 & 5.7 \\
\hline 3 & HT & 72.2 & 9.3 & 1.9 & 1.6 & 0.8 & 3.1 & 4.8 & 9.4 \\
\hline 4 & HT & 57.3 & 5.4 & 1.7 & 1.3 & 0.5 & 2.8 & 4.5 & 7.4 \\
\hline 5 & HT & 60.2 & 5.2 & 2.2 & 2.1 & 0.9 & 3.5 & 5.7 & 9.9 \\
\hline 6 & HT & 59.5 & 5.2 & 1.8 & 1.3 & 0.6 & 2.8 & 4.4 & 8.1 \\
\hline 7 & $\mathrm{HT}$ & 50.1 & 5.1 & 2.5 & 2.0 & 0.5 & 3.3 & 5.7 & 7.4 \\
\hline 8 & HT & 50.6 & 4.6 & 1.7 & 1.1 & 0.5 & 2.6 & 4.1 & 7.4 \\
\hline 9 & HT & 48.6 & 4.4 & 2.1 & 1.0 & 0.5 & 2.5 & 3.8 & 7.4 \\
\hline 10 & HT & 36.2 & 3.7 & 1.5 & 0.9 & 0.7 & 2.4 & 3.1 & 8.8 \\
\hline 11 & HT & 46.9 & 4.9 & 1.8 & 1.6 & 0.9 & 3.1 & 4.7 & 9.9 \\
\hline 12 & DX & 58.9 & 4.1 & 6.4 & 4.2 & 2.6 & 5.1 & 7.3 & 16.9 \\
\hline 13 & EL & 54.6 & 3.9 & 4.6 & 1.8 & 1.2 & 3.4 & 4.7 & 11.5 \\
\hline 14 & EL & 71.1 & 3.3 & 2.5 & 2.4 & 1.0 & 3.8 & 6.1 & 10.5 \\
\hline 15 & EL & 105.7 & 7.3 & 1.0 & 1.0 & 0.8 & 2.5 & 3.3 & 9.4 \\
\hline 16 & $\mathrm{EL}$ & 101.2 & 6.4 & 1.0 & 0.9 & 0.6 & 2.4 & 3.3 & 8.1 \\
\hline 17 & LD & 93.0 & 4.6 & 2.4 & 2.3 & 0.9 & 3.7 & 6.0 & 9.9 \\
\hline 18 & LD & 100.4 & 4.6 & 1.3 & 1.1 & 0.5 & 2.6 & 4.1 & 7.4 \\
\hline 19 & LD & 123.3 & 4.7 & 2.5 & 0.9 & 0.7 & 2.4 & 3.1 & 8.8 \\
\hline 20 & LD & 127.9 & $5.5^{\mathrm{a}}$ & 1.1 & 0.9 & 0.6 & 2.4 & 3.3 & 8.1 \\
\hline 21 & LD & 126.8 & 3.9 & 1.0 & 0.5 & 0.4 & 1.8 & 2.3 & 6.6 \\
\hline 22 & $\mathrm{FH}$ & 79.9 & 3.4 & 3.4 & 2.8 & 1.4 & 4.1 & 6.4 & 12.4 \\
\hline 23 & $\mathrm{FH}$ & 83.1 & 3.9 & 3.5 & 2.4 & 0.8 & 3.7 & 6.3 & 9.4 \\
\hline 24 & $\mathrm{FH}$ & 98.5 & 5.2 & 1.3 & 1.0 & 0.5 & 2.5 & 3.8 & 7.4 \\
\hline 25 & $\mathrm{FH}$ & 68.2 & 2.4 & 2.0 & 1.0 & 0.7 & 2.5 & 3.4 & 8.8 \\
\hline 26 & $\mathrm{FH}$ & 66.8 & 3.4 & 1.3 & 1.1 & 0.6 & 2.6 & 3.9 & 8.1 \\
\hline 27 & $\mathrm{FH}$ & 62.7 & 2.6 & 2.3 & 0.9 & 1.1 & 2.4 & 2.6 & 11.0 \\
\hline 28 & $\mathrm{FH}$ & 94.2 & 6.5 & 1.2 & 0.5 & 0.3 & 1.8 & 2.6 & 5.7 \\
\hline 29 & $\mathrm{FH}$ & 99.3 & 4.4 & 0.9 & 0.7 & 0.3 & 2.0 & 3.3 & 5.7 \\
\hline 30 & $\mathrm{LH}$ & 61.0 & 4.4 & 2.3 & 1.6 & 1.3 & 3.2 & 4.1 & 12.0 \\
\hline 31 & $L X$ & 117.4 & $8.4^{a}$ & 1.2 & 0.8 & 0.7 & 1.8 & 2.3 & 6.6 \\
\hline 32 & $L X$ & 117.3 & 8.6 & 0.6 & 0.5 & 0.4 & 1.4 & 1.6 & 5.7 \\
\hline 33 & $L X$ & 121.9 & 9.2 & 0.4 & 0.3 & 0.3 & 1.8 & 2.3 & 6.6 \\
\hline 34 & $L X$ & 118.1 & 9.1 & 0.7 & 0.5 & 0.4 & 1.6 & 1.9 & 6.6 \\
\hline
\end{tabular}

DX, Dong-Xi; EL, East of Langdao; FH, Five-Hole Cave; HT, Hongtou; LD, Langdao; LH, Lighthouse; LX, Longmen-Xi. Locations are shown in Figure 2. ${ }^{\text {The boulders }}$ for which radiocarbon dating was performed.

\section{Results of numerical simulation} Hongtou (HT)

As a test of the numerical simulation, we calculated the runup of the storm waves at HT by the 2012 typhoon Tembin.

HT is located in the southwest of Lanyu Island. The coral reef terrace is distributed at a height of 3 to $5 \mathrm{~m}$ above the shore and a distance of $45 \mathrm{~m}$ from the shore. The terrace was found to be covered by talus deposits from a distance of $36 \mathrm{~m}$ from the shore (Figure 7A). The boulders were distributed on the coral reef terrace and on the talus deposit beyond the distance of $75 \mathrm{~m}$. The sizes of the boulders ranged from 0.7 to $2.5 \mathrm{~m}$.

The numerical simulation of storm waves by the 2012 typhoon Tembin was employed under conditions where the wave height was $6.6 \mathrm{~m}$ and the wave period was $12 \mathrm{~s}$. The computation time for the numerical simulation was set to $120 \mathrm{~s}$ (Figure 8). We computed the storm 
Table 3 Computed flow depth and flow velocity at the position of boulders by the waves

\begin{tabular}{|c|c|c|c|c|c|c|}
\hline \multirow[t]{2}{*}{ ID } & \multicolumn{2}{|c|}{ 19-year return period } & \multicolumn{2}{|c|}{ 50-year return period } & \multicolumn{2}{|c|}{100 -year return period } \\
\hline & Flow depth (m) & Flow velocity $(\mathrm{m} / \mathrm{s})$ & Flow depth (m) & Flow velocity $(\mathrm{m} / \mathrm{s})$ & Flow depth $(m)$ & Flow velocity $(\mathrm{m} / \mathrm{s})$ \\
\hline 1 & 0.5 & 1.1 & 2.1 & 2.3 & 3.1 & 9.7 \\
\hline 2 & 0.6 & 1.2 & 1.9 & 5.9 & 3.2 & 10.3 \\
\hline 3 & 0.7 & 1.3 & 1.9 & 6.0 & 3.3 & 10.6 \\
\hline 4 & 2.3 & 5.3 & 3.8 & 8.0 & 6.8 & 12.7 \\
\hline 5 & 2.5 & 5.3 & 3.8 & 7.7 & 5.9 & 12.2 \\
\hline 6 & 2.4 & 5.3 & 3.8 & 7.9 & 6.1 & 12.3 \\
\hline 7 & 2.5 & 6.1 & 5.6 & 7.9 & 7.6 & 13.1 \\
\hline 8 & 2.4 & 6.1 & 5.6 & 7.8 & 7.6 & 13.0 \\
\hline 9 & 2.7 & 6.2 & 6.4 & 8.0 & 7.5 & 13.4 \\
\hline 10 & 5.1 & 7.4 & 5.9 & 9.4 & 9.2 & 13.7 \\
\hline 11 & 3.0 & 6.1 & 6.7 & 7.9 & 7.7 & 13.4 \\
\hline 12 & 4.1 & 7.2 & 5.4 & 9.6 & 6.4 & 11.0 \\
\hline 13 & 4.8 & 9.6 & 5.4 & 12.2 & 7.0 & 12.7 \\
\hline 14 & 5.3 & 8.9 & 5.9 & 12.1 & 5.9 & 12.8 \\
\hline 15 & 2.3 & 5.5 & 3.3 & 7.9 & 5.7 & 9.5 \\
\hline 16 & 2.6 & 6.3 & 5.0 & 8.8 & 6.3 & 10.1 \\
\hline 17 & 4.0 & 8.2 & 4.7 & 9.9 & 6.8 & 10.7 \\
\hline 18 & 4.5 & 7.5 & 5.4 & 9.4 & 6.1 & 10.1 \\
\hline 19 & 1.3 & 4.9 & 2.4 & 7.0 & 4.5 & 8.3 \\
\hline 20 & 1.3 & 4.4 & 2.2 & 6.9 & 3.3 & 8.2 \\
\hline 21 & 1.3 & 4.5 & 2.3 & 6.9 & 3.4 & 8.1 \\
\hline 22 & 5.9 & 9.9 & 9.4 & 11.5 & 10.0 & 12.3 \\
\hline 23 & 4.4 & 9.3 & 8.1 & 10.8 & 9.3 & 11.8 \\
\hline 24 & 3.1 & 7.1 & 6.7 & 9.5 & 6.8 & 10.8 \\
\hline 25 & 5.7 & 10.1 & 6.4 & 12.0 & 8.3 & 12.6 \\
\hline 26 & 5.3 & 10.1 & 6.7 & 11.5 & 8.2 & 12.6 \\
\hline 27 & 5.5 & 10.3 & 7.3 & 11.9 & 8.3 & 12.9 \\
\hline 28 & 4.7 & 8.0 & 5.2 & 9.8 & 6.1 & 11.5 \\
\hline 29 & 3.1 & 7.1 & 6.8 & 9.5 & 6.8 & 10.8 \\
\hline 30 & 5.1 & 8.5 & 6.4 & 10.0 & 9.3 & 13.2 \\
\hline 31 & 0.5 & 0.8 & 1.1 & 2.0 & 2.9 & 5.3 \\
\hline 32 & 0.5 & 0.8 & 1.1 & 2.0 & 2.9 & 5.3 \\
\hline 33 & 0.2 & 0.2 & 1.0 & 1.6 & 3.0 & 5.0 \\
\hline 34 & 0.5 & 0.7 & 1.1 & 1.9 & 2.9 & 5.2 \\
\hline
\end{tabular}

waves using the topography data of different survey lines that were $30 \mathrm{~m}$ apart from each other, and we estimated the effects of the differences in the topographical data. The lines $X-X^{\prime}$ and $Y-Y^{\prime}$ have similar topographies (Figure 9A) with differences in topography of approximately $1 \mathrm{~m}$ (Figure 9B). The computed flow depth and flow velocity of X-X' and $Y-Y^{\prime}$ have similar trends (Figure 9C, $\mathrm{D}$, respectively), and the runup distances of $\mathrm{X}-\mathrm{X}^{\prime}$ and Y-Y' are similar: 66.0 and $69.5 \mathrm{~m}$, respectively. When the reef width was set as $0 \mathrm{~m}$, the distributions of flow depth and flow velocity were similar to those of the other case, which suggests that small differences in topography would have negligible effects on the results of the numerical simulation. The maximum runup height and flow velocity in the first $120 \mathrm{~s}$ were selected. The maximum flow depth, maximum flow velocity, and maximum runup heights were calculated using the maximum value within the computation time. The computed maximum runup heights and inundation distance from the shore under these conditions were 8.7 and $66 \mathrm{~m}$, 

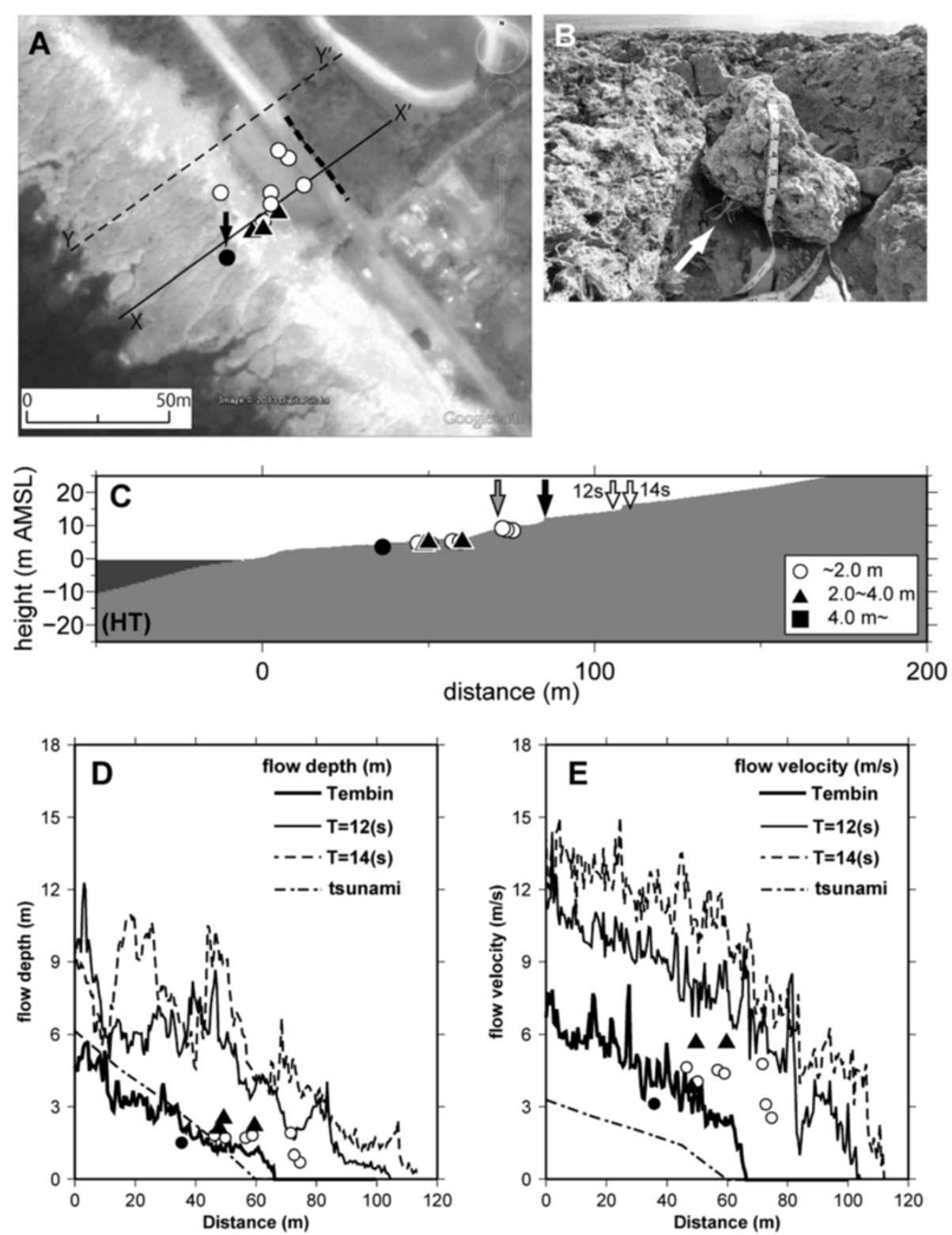

Figure 7 Result of the numerical simulation at Hongtou (HT). (A) Location of boulders at HT (base map is from Google Earth). The dashed line shows the inundation line. The arrow shows the boulder moved by the typhoon Tembin. The solid circle shows the boulder moved by the typhoon Tembin. (B) Photograph of a boulder. The white arrow shows the grass that appeared to be growing downwards. (C) Topographic profile. Boulder size is classified by length of the long axis. The gray and solid arrows denote the computed and observed inundation limits by the typhoon Tembin, respectively. The open arrows show the computed inundation limits by waves with a return period of 50 years. (D) Maximum flow depth. The circles and triangles show the a-axis length of boulders. (E) Maximum flow velocity. The circles and triangles show the flow velocity of boulders (rolling). The bold lines in (D) and (E) show the maximum flow depth and maximum flow velocity by the typhoon Tembin. The dot-dashed lines in (D) and (E) show the maximum flow depth and maximum flow velocity, respectively, from the fault model of Hsu et al. (2012).

respectively (Figure 7C,D). The observed runup height was $11.4 \mathrm{~m}$.

The computed maximum inundation depth was $6 \mathrm{~m}$ at the shore and decreased inland. The maximum flow velocity was $9 \mathrm{~m} / \mathrm{s}$ at the shore and this, too, decreased inland. Here, we estimated the maximum flow velocity by averaging the flow velocity from the inundated surface to the bottom.

The flow velocity $(5.0 \mathrm{~m} / \mathrm{s})$ at the distance of $36 \mathrm{~m}$ is only larger than the flow velocity $(3.1 \mathrm{~m} / \mathrm{s})$ necessary to cause boulders at that location to move by rolling (Figure 7E). 

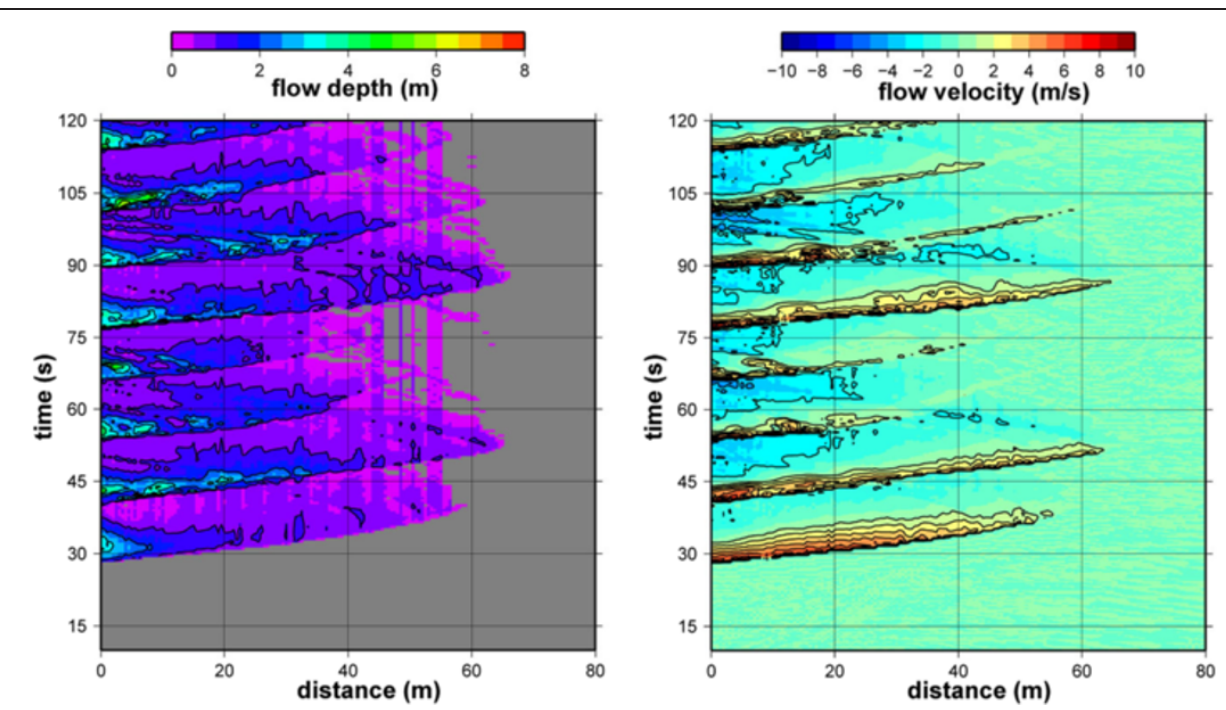

Figure 8 Space-time distribution of flow depth (left) and flow velocity (right) for the case at HT.
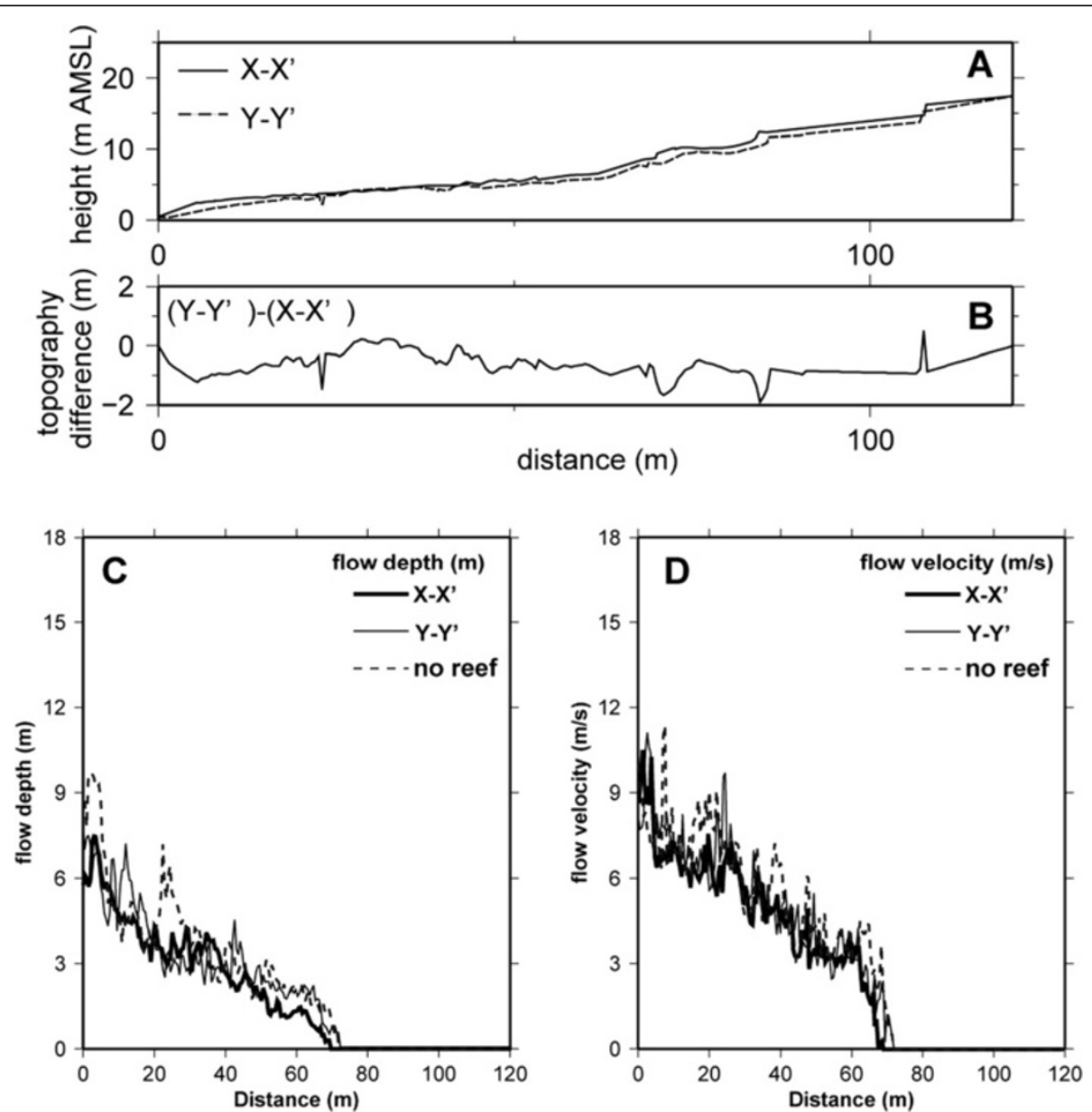

Figure 9 Computed flow depth and flow depth at different survey lines. (A) Topography of survey lines $X-X^{\prime}$ and $Y$-Y'. (B) Difference in topography between $X-X^{\prime}$ and $Y-Y^{\prime}$, which is calculated by subtracting the topography of $X-X^{\prime}$ from that of $Y-Y^{\prime}$ (Figure 7). (C) Maximum flow depth. No reef is the model with topography the same as $X-X^{\prime}$ and where the reef width is set to 0 . (D) Maximum flow velocity. 
The boulder at the distance of $36 \mathrm{~m}$ was marked, which suggests rolling transportation by the waves of the typhoon. The boulder also held some grass that appeared to be growing downwards (Figure 7B), suggesting that the boulder had recently been moved by rolling. Such marks were not found on the other boulders. If the boulders were to move by sliding, a flow velocity of 1.8 to $3.5 \mathrm{~m} / \mathrm{s}$ would be required. As the computed flow velocities were over 3 to $4 \mathrm{~m} / \mathrm{s}$ at the positions of the boulders (distances within $60 \mathrm{~m}$ ) (Figure 7E), it would be expected that almost all boulders would start to move if boulders were transported by sliding. On the other hand, the boulders would not move within the distance range of 40 to $80 \mathrm{~m}$, but would move at the distance of $36 \mathrm{~m}$, if the mode of transport were rolling (Figure 7E). Moreover, if the boulders were to move by saltation, a flow velocity of 5.7 to $9.9 \mathrm{~m} / \mathrm{s}$ would be required. This flow velocity is larger than the computed flow velocity at the positions of the boulders. Thus, we assume that the boulders moved by rolling. Thus, the calculation could well reproduce the runup of actual storm wave, and the numerical simulation using the CADMAS-SURF is useful for the reproduction of storm waves.

The inundation depths and flow velocities at the positions of the boulders $(x=30$ to $80 \mathrm{~m})$ were 0.0 to $3.2 \mathrm{~m}$ and 0.0 to $2.1 \mathrm{~m} / \mathrm{s}$, respectively, and the inundation distance and runup height of the waves were 60 and $6.4 \mathrm{~m}$, respectively.

\section{Dong-Xi (DX)}

DX is located in the northeastern part of the island. The coral reef terrace (elevation 2 to $4 \mathrm{~m}$ above sea level) is distributed from the shore to at a distance of $70 \mathrm{~m}$ (Figure 10A). Talus deposit and sand dunes are distributed in the inland area of DX. A boulder was located at a distance of $58.9 \mathrm{~m}$ from the shore (Figure 10B) and had an $a$-axis length of $6.4 \mathrm{~m}$. The flow velocity required for rolling was estimated from the size of the boulder to be $7.3 \mathrm{~m} / \mathrm{s}$. The inundation distance and height of the waves at the period of $12 \mathrm{~s}$ reached 142 and $10.6 \mathrm{~m}$, respectively (Figure 10C). The computed maximum inundation depth at the shore was $12 \mathrm{~m}$, and the maximum flow velocity was $11.9 \mathrm{~m} / \mathrm{s}$ (Figure 10E). The inundation depth and flow velocity at the position of the boulder were $5.0 \mathrm{~m}$ and $9.5 \mathrm{~m} / \mathrm{s}$, respectively (Figure 10D,E). The inundation distance and runup height of the wave in the wave period of $14 \mathrm{~s}$ increased to 175 and $13.9 \mathrm{~m}$, respectively. The inundation depth when the wave period was $14 \mathrm{~s}$ was larger than that when the wave period was $12 \mathrm{~s}$.

The inundation depth and flow velocity at the position of the boulder $(x=60 \mathrm{~m})$ caused by the tsunami were $4.3 \mathrm{~m}$ and $4.1 \mathrm{~m} / \mathrm{s}$, respectively, and the inundation distance and runup height of the waves were 180 and $10.4 \mathrm{~m}$, respectively.

\section{East of Langdao (EL)}

EL is located in the north of the island. The coral reef terrace (elevation 3 to $5 \mathrm{~m}$ above sea level) is distributed from the shore to a distance of $90 \mathrm{~m}$ in EL (Figure 11A). Talus deposit and sand dunes, which are covered by vegetation, are distributed further inland than at DX. Two boulders, whose $a$-axis lengths were 4.6 and $2.5 \mathrm{~m}$, were located 54.6 and $71.1 \mathrm{~m}$ from the shore, respectively (Figure 11B). The flow velocities required for rolling were estimated from the sizes of the boulders at 4.7 to $6.1 \mathrm{~m} / \mathrm{s}$. The inundation distance and height of the waves for the period of $12 \mathrm{~s}$ reached 128 and $10.1 \mathrm{~m}$, respectively (Figure 11C). The computed maximum inundation depth was $7.0 \mathrm{~m}$ at the shore (Figure 11D), and the maximum flow velocity was $10.9 \mathrm{~m} / \mathrm{s}$ (Figure 11E). The inundation depth and flow velocity at the position of the largest boulder were $6 \mathrm{~m}$ and $9 \mathrm{~m} / \mathrm{s}$, respectively. The inundation distance and runup height of the wave in the wave period of $14 \mathrm{~s}$ increased to 168 and $13.4 \mathrm{~m}$, respectively. The inundation depth when the wave period was $14 \mathrm{~s}$ was larger than that when the wave period was $12 \mathrm{~s}$.

The inundation depths and flow velocities at the positions of the boulders $(x=60$ to $110 \mathrm{~m})$ caused by the tsunami were 5.8 to $6.0 \mathrm{~m}$ and 4.1 to $5.5 \mathrm{~m} / \mathrm{s}$, respectively, and the inundation distance and runup height of the waves were 180 and $9.7 \mathrm{~m}$, respectively.

\section{Langdao (LD)}

LD is located just to the west of EL. The coral reef terrace (elevation 2 to $3 \mathrm{~m}$ above sea level) is distributed from the shore to a distance of $80 \mathrm{~m}$ (Figure 12A). Sand dunes are distributed inland. The boulders were distributed at distances ranging from 93 to $128 \mathrm{~m}$ from the shore. The sizes of boulders were in the range 1.0 to $2.5 \mathrm{~m}$ (Figure 12B). Radiocarbon dating of the largest coral boulder at LD returned ages of Cal AD 1670 to 1810 (beta ID = 371293) (Table 2). The flow velocities required for rolling were estimated from the sizes of boulders at 2.3 to $6.0 \mathrm{~m} / \mathrm{s}$. The inundation distance and runup height of the waves for the period of $12 \mathrm{~s}$ reached 142 and $10.2 \mathrm{~m}$, respectively (Figure 12C), and the computed maximum inundation depth was $8.1 \mathrm{~m}$ at the shore (Figure 12D). The maximum flow velocity was $10.4 \mathrm{~m} / \mathrm{s}$ at the shore (Figure 12E). The inundation depths and flow velocities at the positions of the boulder were 1 to $3 \mathrm{~m}$ and 3 to $6 \mathrm{~m} / \mathrm{s}$, respectively. The inundation distance and runup height of the wave for the period of $14 \mathrm{~s}$ increased to 190 and $13.2 \mathrm{~m}$, respectively.

The inundation depths and flow velocities at the positions of the boulders ( $x=90$ to $130 \mathrm{~m}$ ) caused by the tsunami were 5.2 to $6.7 \mathrm{~m}$ and 5.1 to $5.9 \mathrm{~m} / \mathrm{s}$, respectively, and the inundation distance and runup height of the waves were 240 and $18.2 \mathrm{~m}$, respectively. 

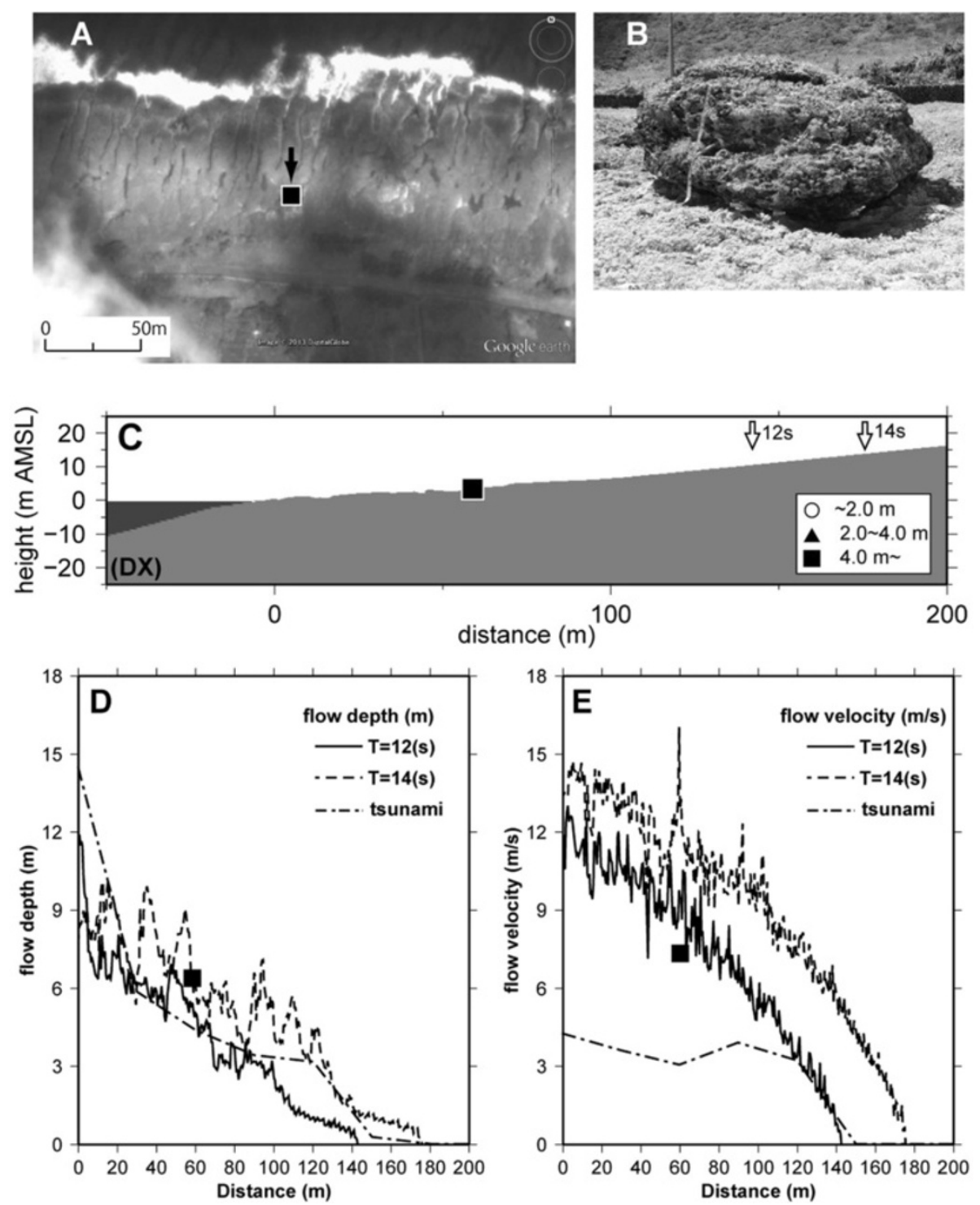

Figure 10 Result of the numerical simulation at Dong-Xi (DX). (A) Location of boulders at DX (base map is from Google Earth). The bold arrow shows the boulder which is the maximum in this area. (B) Photograph of a boulder. (C) Topographic profile. Boulder size is classified by length of the long axis. (D) Maximum flow depth. The square shows the $a$-axis length of boulders. (E) Maximum flow velocity. The square denotes the flow velocity (rolling) of boulders.

\section{Five-Hole Cave (FH)}

$\mathrm{FH}$ is located in the northwest of the island. The coral reef terrace (elevation 2 to $3 \mathrm{~m}$ above sea level) is distributed from the shore to a distance of $60 \mathrm{~m}$ (Figure 13A). Sand dunes and talus deposits are distributed in the inland area. The boulders were distributed at distances of 79.9 to $99.3 \mathrm{~m}$. The lengths of the $a$-axis of the boulders ranged from 0.9 to $3.5 \mathrm{~m}$ (Figure 13B). The flow velocities required for rolling were estimated from the sizes of the boulders to be 2.6 to $6.4 \mathrm{~m} / \mathrm{s}$ (Table 2). The inundation distance and height of the waves for the period of $12 \mathrm{~s}$ reached 142 and $10.9 \mathrm{~m}$, respectively (Figure 13C). The computed maximum inundation depth was $8.6 \mathrm{~m}$ at the shore (Figure 13D), and the maximum flow velocity was $12.2 \mathrm{~m} / \mathrm{s}$ (Figure 13E). The inundation depths and flow velocities at the positions of the boulders were 3 to $9 \mathrm{~m}$ and 8 to $9 \mathrm{~m} / \mathrm{s}$, respectively. The inundation distance and runup height of the wave for the period of $14 \mathrm{~s}$ increased to 164 and $13.9 \mathrm{~m}$, respectively. The inundation depth when the wave period was $14 \mathrm{~s}$ was larger than that when the wave period was $12 \mathrm{~s}$.

The inundation depths and flow velocities at the positions of the boulders ( $x=60$ to $100 \mathrm{~m}$ ) caused by the tsunami were 1.3 to $2.8 \mathrm{~m}$ and $3.8 \mathrm{~m} / \mathrm{s}$, respectively, and the inundation distance and runup height of the waves were 180 and $8.6 \mathrm{~m}$, respectively. 

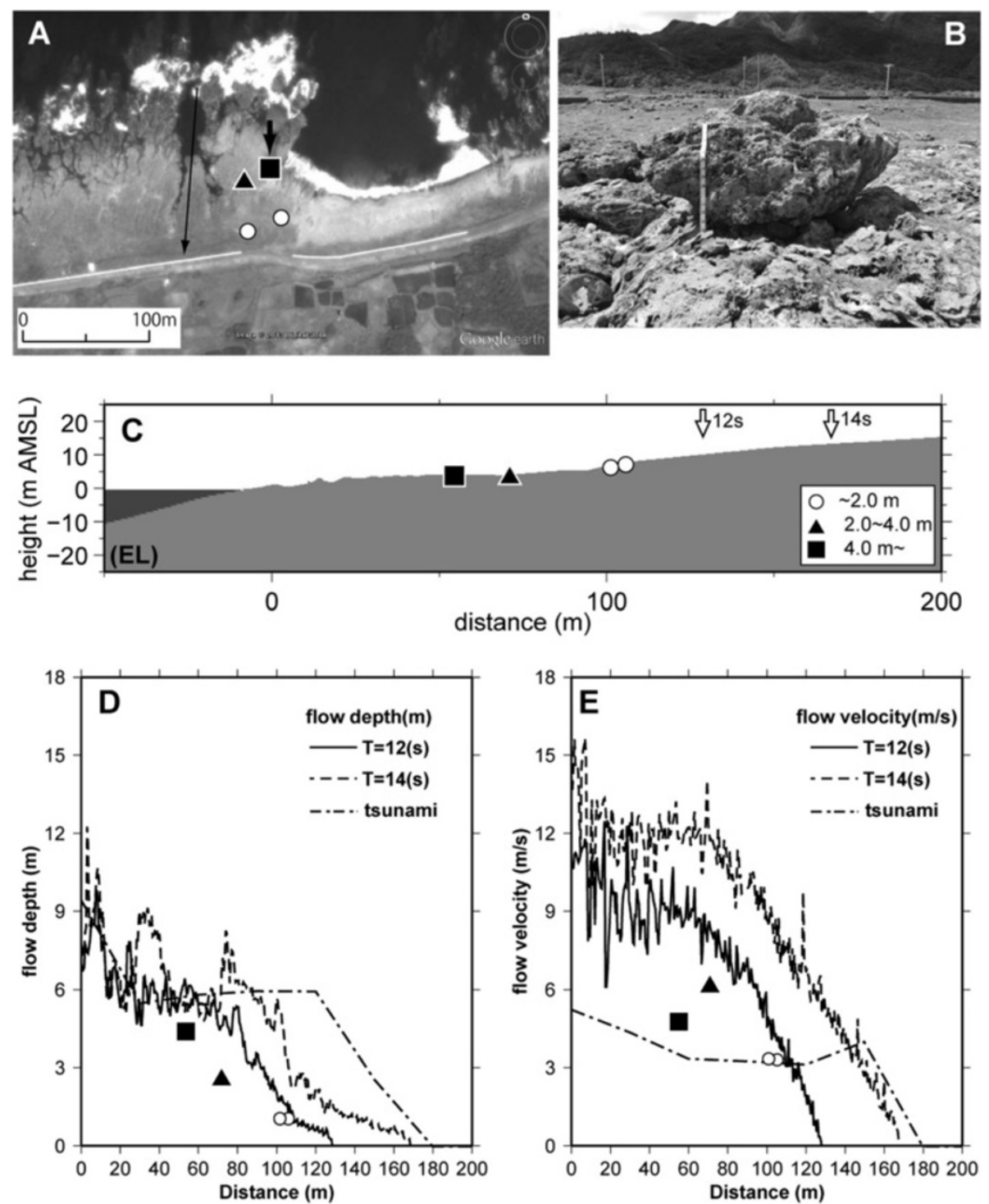

Figure 11 Result of the numerical simulation at east of Langdao (EL). (A) Location of boulders at EL (base map is from Google Earth). The bold arrow shows the boulder which is the maximum in this area. The thin line arrow shows the direction of the survey line. (B) Photograph of a boulder. (C) Topographic profile. Boulder size is classified by length of the long axis. (D) Maximum flow depth. The circles, triangle, and square show the $a$-axis length of boulders. (E) Maximum flow velocity. The circles, triangle, and square denote the flow velocity (rolling) of boulders. The dot-dashed lines in (D) and (E) show the maximum flow depth and maximum flow velocity, respectively, caused by the tsunami (Hsu et al. 2012).

\section{Lighthouse (LH)}

$\mathrm{LH}$ is also located in the northwest of the island. The coral reef terrace (elevation 2 to $5 \mathrm{~m}$ above sea level) is distributed from the shore to a distance of $65 \mathrm{~m}$ (Figure 14A). Talus deposit is distributed in the inland area. A boulder whose $a$-axis length was $2.3 \mathrm{~m}$ was located at a distance of $61 \mathrm{~m}$ from the shore (Figure 14B). The flow velocity required for rolling was estimated from the size of the boulder to be $4.1 \mathrm{~m} / \mathrm{s}$ (Table 2). The inundation distance and height of the waves for the period of $12 \mathrm{~s}$ reached 112 and $12.3 \mathrm{~m}$, respectively (Figure 14C). The computed maximum inundation depth was $8.2 \mathrm{~m}$ at the shore (Figure 14D), and the maximum flow velocity was $11.2 \mathrm{~m} / \mathrm{s}$ (Figure 14E). The inundation depth and flow velocity at the position of the boulder were $6 \mathrm{~m}$ and $9 \mathrm{~m} / \mathrm{s}$, respectively. The inundation distance and runup height of the wave for the wave period of $14 \mathrm{~s}$ increased to 118 and $17.7 \mathrm{~m}$, respectively.

The inundation depths and flow velocities at the positions of the boulders $(x=60 \mathrm{~m})$ caused by the tsunami were $1.6 \mathrm{~m}$ and $3.2 \mathrm{~m} / \mathrm{s}$, respectively, and the inundation distance and runup height of the waves were 120 and $6.6 \mathrm{~m}$, respectively. 

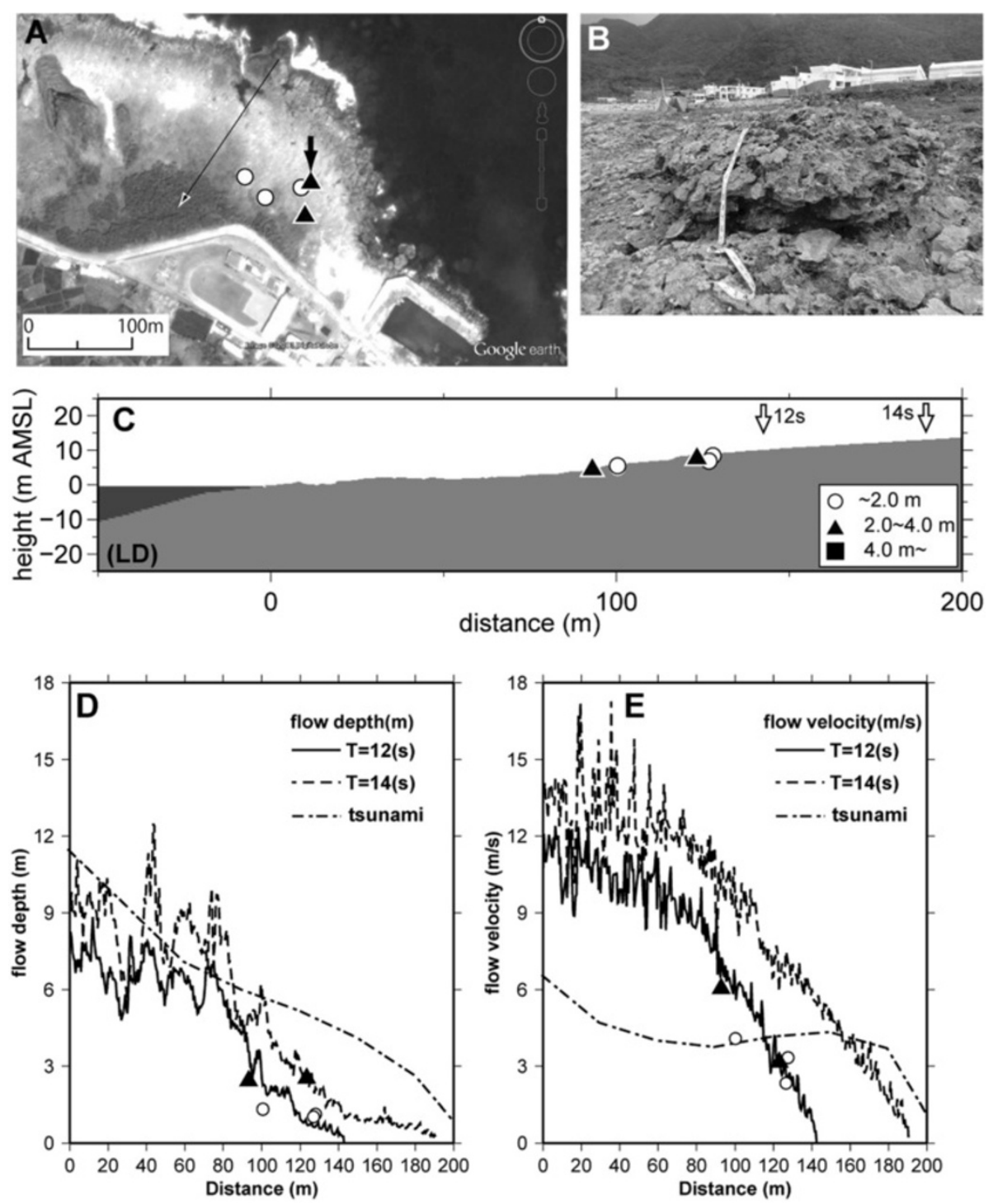

Figure 12 Result of the numerical simulation at Langdao (LD). (A) Location of boulders at LD (base map is from Google Earth). The bold arrow shows the boulder which is the maximum in this area. The thin line arrow shows the direction of the survey line. (B) Photograph of a boulder. Radiocarbon dating was performed on this coral boulder. (C) Topographic profile. Boulder size is classified by length of the long axis. (D) Maximum flow depth. The circles and triangles show the $a$-axis length of boulders. (E) Maximum flow velocity. The circles and triangles denote the flow velocity (rolling) of boulders. The dot-dashed lines in (D) and (E) show the maximum flow depth and maximum flow velocity, respectively, caused by the tsunami (Hsu et al. 2012).

\section{Longmen-Xi (LX)}

LX is located in the southeast of the island. The coral reef terrace (elevation 4 to $8 \mathrm{~m}$ above sea level) is distributed from the shore to a distance of $90 \mathrm{~m}$ (Figure 15A). Sand dunes are distributed in the inland area and talus deposits are distributed as far as $110 \mathrm{~m}$ from the shore. The boulders were found to be distributed at a distance of $120 \mathrm{~m}$ from the shore (Figure 15B,C). The lengths of the $a$-axis of the boulders were about $1 \mathrm{~m}$ or less. Radiocarbon dating of the largest coral boulders at LX returned ages of Cal BC 4320 to 4160 (beta ID = 371294) (Table 2). The flow velocity required for rolling was estimated from the size of the boulders to be $2.0 \mathrm{~m} / \mathrm{s}$. The inundation distance and height of the waves for the period of $12 \mathrm{~s}$ reached 105 and $8.0 \mathrm{~m}$, respectively (Figure 15D). The computed maximum inundation depth was $6.9 \mathrm{~m}$ at the shore, and the maximum inundation depth decreased inland (Figure 15E). The maximum flow velocity was $12.8 \mathrm{~m} / \mathrm{s}$ at the shore (Figure 15F). Waves cannot reach the position of the boulders when the wave period is $12 \mathrm{~s}$. However, the inundation depth and flow velocity were $1.3 \mathrm{~m}$ and $1.8 \mathrm{~m} / \mathrm{s}$, respectively, when the wave period was $14 \mathrm{~s}$; this flow velocity is similar to that required to initiate movement of the boulders. 

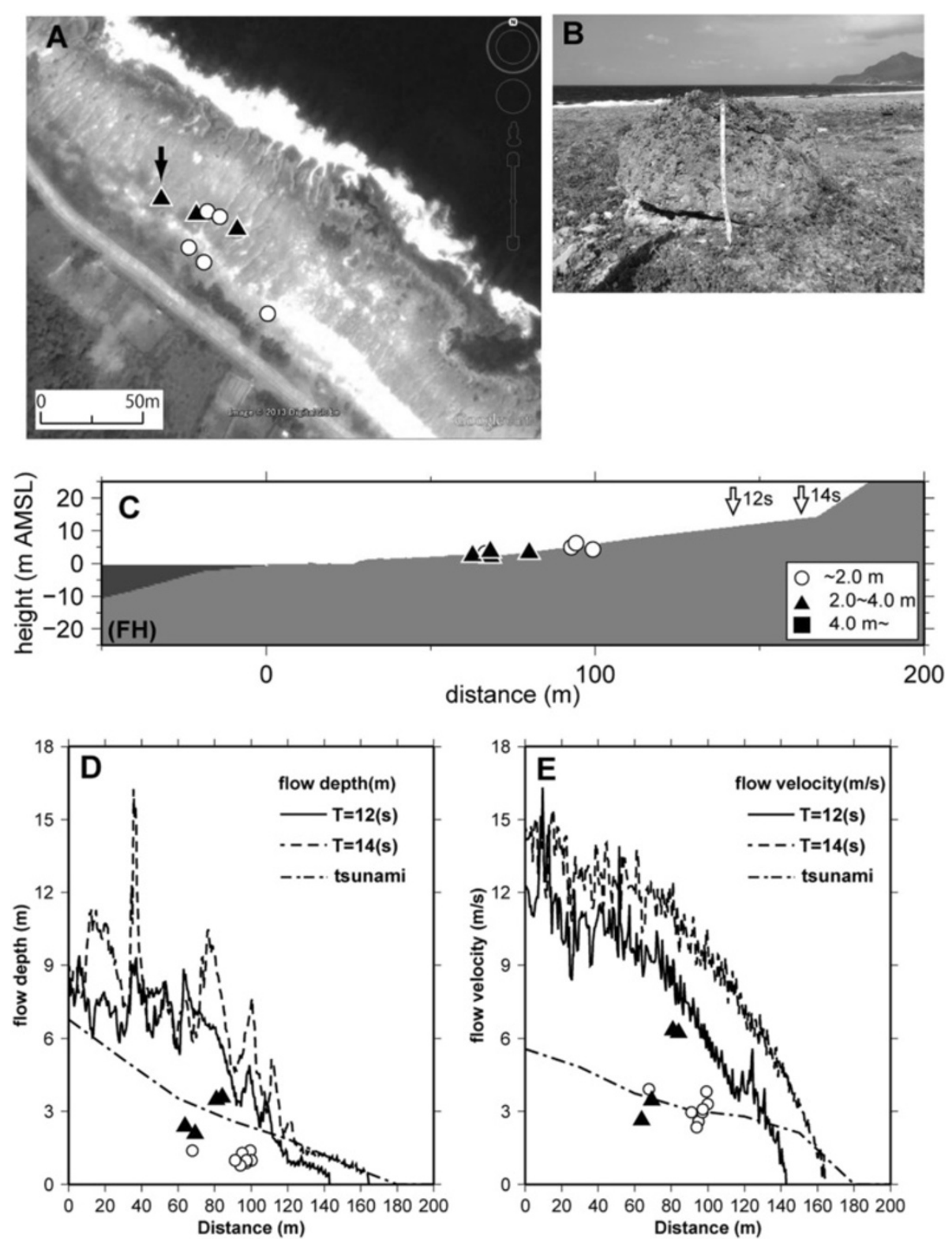

Figure 13 Result of the numerical simulation at Five-Hole Cave (FH). (A) Location of boulders at FH (base map is from Google Earth). The bold arrow shows the boulder which is the maximum in this area. (B) Photograph of a boulder. (C) Topographic profile. Boulder size is classified by length of the long axis. (D) Maximum flow depth. The circles and triangles show the $a$-axis length of boulders. (E) Maximum flow velocity. The circles and triangles denote the flow velocity (rolling) of boulders. The dot-dashed lines in (D) and (E) show the maximum flow depth and maximum flow velocity, respectively, caused by the tsunami (Hsu et al. 2012).

The inundation depths and flow velocities at the positions of the boulders $(x=120 \mathrm{~m})$ caused by the tsunami were $0.4 \mathrm{~m}$ and $0.3 \mathrm{~m} / \mathrm{s}$, respectively, and the inundation distance and runup height of the waves were 120 and $12.0 \mathrm{~m}$, respectively.

\section{Discussion}

We employed a numerical simulation of storm waves with a 50-year return period on the shore of Lanyu Island and estimated whether the boulders could be moved by the storm waves. The results showed that all large boulders on the Lanyu Island shore could be moved by storm waves with a 50-year return period.

Plots of boulder volume and $a$-axis length versus distance from the shore exhibit weak and moderate correlation ( $r=0.21$ and 0.48$)$, respectively. The exponential landward-fining trend of boulder size distribution is found in Kudaka Island, Ryukyu (Goto et al. 2009). The weights of largest size boulders and average-size boulders have correlation $\left(R^{2}=0.6962\right.$ and $\left.R^{2}=0.702\right)$ with 

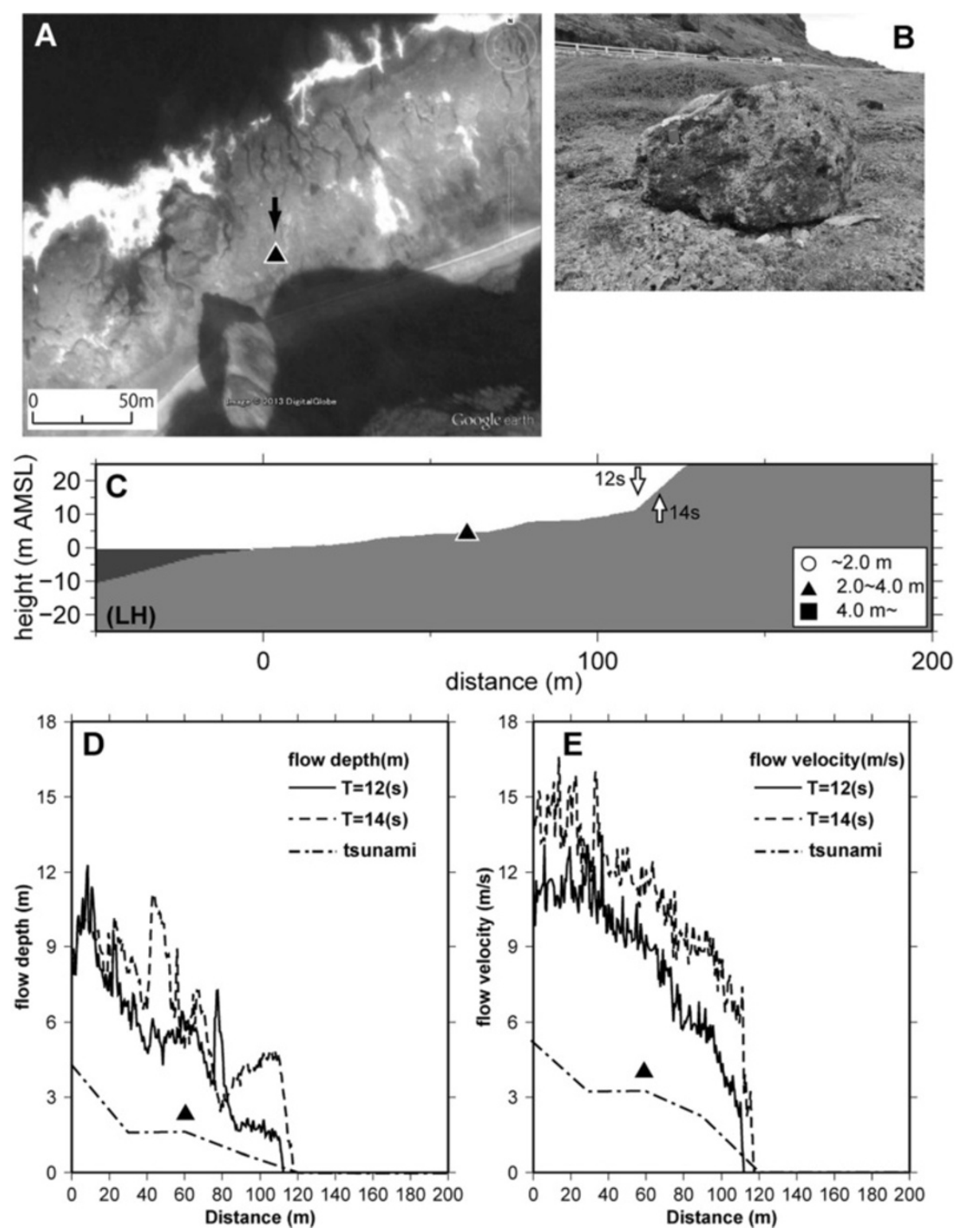

Figure 14 Result of the numerical simulation at Lighthouse (LH). (A) Location of boulders at LH (base map is from Google Earth). The bold arrow shows the boulder which is the maximum in this area. (B) Photograph of a boulder. (C) Topographic profile. Boulder size is classified by length of the long axis. (D) Maximum flow depth. The triangle shows the a-axis length of boulders. (E) Maximum flow velocity. The triangle denotes the flow velocity (rolling) of boulders. The dot-dashed lines in (D) and (E) show the maximum flow depth and maximum flow velocity, respectively, caused by the tsunami (Hsu et al. 2012).

distance from the reef edge on Kudaka Island. These patterns are controlled by storm waves because the height of storm waves decreases exponentially towards the reef flat (Egashira et al. 1985). On the other hand, a bimodal distribution of boulders is found on Ishigaki Island, Ryukyu, which suggests that large tsunamis affected the boulders in addition to the storms (Goto et al. $2010 \mathrm{~b})$. One distribution is near the reef edge, and the other is far from the reef edge (approximately $>700 \mathrm{~m}$ ). The former is caused by the storm waves and the latter by the tsunamis. If we apply the mechanism of distribution of boulders on Ryukyu to that on Lanyu Island, the landward-fining boulder size and lack of large boulders far from the shore suggest that the boulders would have been transported by storm waves on Lanyu Island.

Obviously, this cannot rule out the possibility that the boulders on Lanyu Island could have been transported by tsunamis. However, the computed flow velocities of tsunamis that originated in the area of the Ryukyu Trench were too small to move the boulders. This suggests that the boulders could not be moved by tsunamis if Mw8.7 earthquakes occurred in the Ryukyu Trench. 

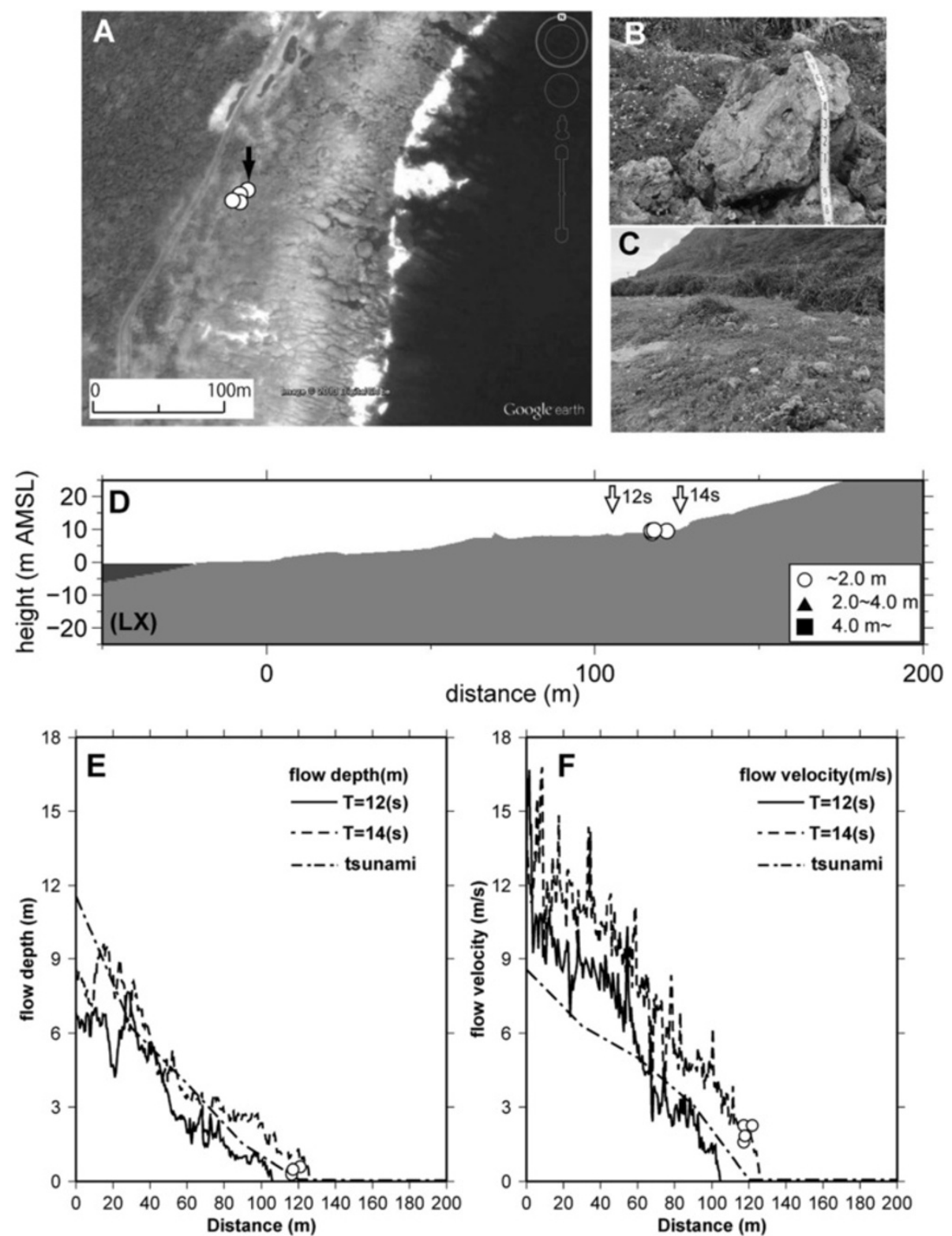

Figure 15 Result of the numerical simulation at Longmen-Xi (LX). (A) Location of boulders at LX (base map is from Google Earth). The bold arrow shows the boulder which is the maximum in this area. (B) Photograph of a boulder. Radiocarbon dating was performed on this coral boulder. (C) Photograph of a talus deposit area where coral boulders were distributed. (D) Topographic profile. Boulder size is classified by length of the long axis. (E) Maximum flow depth. The circles show the $a$-axis length of boulders. (F) Maximum flow velocity. The circles denote the flow velocity (rolling) of boulders. The dot-dashed lines in (E) and (F) show the maximum flow depth and maximum flow velocity, respectively, caused by the tsunami (Hsu et al. 2012).

Moreover, the possibility that the boulders would be moved by storm waves with a 50 -year return period is much greater than the possibility that the boulders would be moved by tsunamis, because the occurrence of tsunamis is rare near Lanyu Island. Tsunamis observed at Lanyu Island since 1950 have typically been about $0.1 \mathrm{~m}$ high (Lau et al. 2010). The absence of any significant tsunamis since that date suggests that tsunamis of equivalent height to storm waves with a 50-year return period occur less often than such storm waves. Radiocarbon dating of the boulders at LD (Figure 12B) and LX (Figure 15B) provided dates of Cal AD 1670 to 1810 and Cal BC 4320 to 4160, respectively. This suggests that the event that transported the boulder at LD onto land occurred sometime after 340 years ago. The age of the boulder at LX is similar to that of the lower coral terrace (Inoue et al. 2011), which suggests that the lower coral terrace was broken and transported at LX. Although the 
event at LX would be estimated as occurring sometime after 6,330 years ago, the detail has not yet been determined.

If the evidence regarding tsunamis in folklore or historical documents is reliable, it appears that the boulders in this region were moved by past tsunamis. However, we have no data to suggest that the boulders on Lanyu Island were transported by tsunamis. Thus, we conclude that the boulders were moved by storm waves, particularly those associated with typhoons. Based on the numerical simulation, the boulders could not have been moved by the tsunamis, but instead could have been moved by storm waves. This suggests that the boulders moved by tsunamis would be relocated by storm waves, if the runup heights of the tsunamis were less than 10 to $15 \mathrm{~m}$, which is almost equal to that of the computed tsunamis.

On the island of Hawaii, basalt boulders reached distances of $300 \mathrm{~m}$ from the shore and elevations of $10.4 \mathrm{~m}$ (Goff et al. 2006; Richmond et al. 2011). It has been estimated that these boulders were moved by a combination of the 1975 Kalapana tsunami, 1868 tsunami, and other past tsunamis and that movement associated with storm waves was limited to distances within $100 \mathrm{~m}$ of the shore. The boulder distribution on Lanyu Island shows that most boulders are distributed within a distance of $100 \mathrm{~m}$ of the shore. This is consistent with boulders distributed by storm waves on Hawaii Island (Richmond et al. 2011). Weak or moderate correlations between the distance from the shore and the size of boulders suggest that the distribution of boulders could be controlled by the short-wavelength waves that affect the nearshore but cannot reach further inland. When boulders are moved by tsunamis, the relationship between boulder size and distance from the shore exhibits particularly low correlation.

We assumed that the boulders were transported in rolling mode. However, if the boulders were transported in sliding mode, the required wave heights to move the boulders would be smaller than those with a return period of 50 years (Table 2). This suggests that the boulders could be moved by the small amplitude waves that have a return period of 50 years or less if the boulders were moved in sliding mode. In any case, the boulders could be transported by the storm waves with a return period of 50 years or less.

The boulders at Jiupeng are distributed at distances of 30 to $76 \mathrm{~m}$ from the shore (Matta et al. 2013). Boulder sizes were found to be in the range 4.2 to $5.5 \mathrm{~m}$, which is within the range of boulder sizes observed on Lanyu Island. This suggests that the boulders at Jiupeng would have been moved by storm waves. Even if the boulders were transported to the coast by paleo-tsunamis, subsequent storms would have moved them.
These results suggest that boulders at distances within $100 \mathrm{~m}$ of the shore could be moved by storm waves with a 50-year return period. If the boulders were distributed at distances beyond the inundation area of the estimated storm waves, or if the estimated flow velocities required to initiate movement of the boulders were much larger than those of the storm waves, it would have been plausible that these boulders were moved by tsunamis. The estimation of flow velocity and inundation depth from numerical simulations of storm waves based on accurate topographic surveys would be a useful tool for identifying whether tsunamis or storms transported the numerous boulders onshore.

\section{Conclusions}

We surveyed the sizes and distances from the shore of boulders on Lanyu Island, Taiwan, and investigated whether they could have been moved by storm waves. The results suggest that boulder sizes decreased with distance from the shore. The boulder volume and $a$-axis length versus distance from the shore exhibited weak and moderate correlation $(r=0.21$ and 0.48$)$, respectively. The landward-fining boulder size distribution and lack of large boulders far from the shore suggest that the boulders on Lanyu Island would have been transported by storm waves.

The estimated maximum flow velocities obtained from numerical simulations of storm waves were larger than required to initiate movement of the boulders. This also suggests that the boulders would have been moved by storm waves with a 50 -year return period.

Obviously, this does not rule out the occurrence of large paleo-tsunamis having struck Lanyu Island. However, the numerical simulations of the tsunamis generated by Mw8.7 earthquakes from the Ryukyu Trench could not move most of the boulders. Moreover, storm waves could transport boulders up to $100 \mathrm{~m}$ from the shore, and the sizes of these boulders decrease with distance from the shore. Thus, boulders that do not conform to this trend could possibly be boulders transported by tsunamis. Verification of the method of transportation of boulders based on numerical simulations would be useful in areas where the coral reef is not developed and storm waves can reach the shore.

\section{Competing interests}

The authors declare that they have no competing interests.

\section{Authors' contributions}

All authors carried out the observation. MN analyzed the data, carried out the numerical simulation, and drafted the manuscript. All authors read and approved the final manuscript.

\section{Acknowledgements}

We thank the two anonymous reviewers whose comments helped us improve and refine the manuscript significantly. We would like to give special thanks to Katsumi Nakao, a professor in J. F. Oberlin University, for his 
helpful support in the Lanyu Island. Thanks are offered also to the Japan Meteorological Agency for providing the Grid Point Value data. This work was supported by JSPS KAKENHI Grant Numbers 23540498 and 24651277.

\section{Received: 19 March 2014 Accepted: 17 September 2014}

Published: 30 September 2014

\section{References}

Ando M, Nakamura M, Lin CH (2013) Tsunami folklore and possible tsunami source on the eastern coast of Taiwan. Terr Atmos Ocean Sci 24:951-961, doi:10.3319/TAO.2013.07.12.01(T)

Araoka D, Yokoyama Y, Suzuki A, Goto K, Miyagi K, Miyazawa K, Matsuzaki H, Kawahata H (2013) Tsunami recurrence revealed by Porites coral boulders in the southern Ryukyu Islands, Japan. Geology 41, doi:10.1130/G34415.1

Asai E, Ogawa N (1935) The myths and traditions of the Formosan native tribes (reprinted edition). Toko Shoin, Tokyo (in Japanese)

Chen YG, Liu TK (1992) Vertical crustal movement of a tectonic uplifting volcanic island-Lutao. J Geol Soc China 35:231-246

Coastal Development Institute of Technology (2001) Research and development of numerical wave channel "CADMAS-SURF", coastal channel. Coastal Dev Inst Technol CDIT Libl 12:1-296 (in Japanese)

Egashira K, Fukuda I, Kishira Y, Nishimura T (1985) Field measurement of the wave deformation on the reef. Proc Coastal Eng JSCE 32:90-94 (in Japanese)

General Bathymetric Chart of the Oceans (2010) British Oceanographic Data Centre., http://www.gebco.net/data_and_products/ gridded_bathymetry_data/. Accessed 6 July 2014

Global Atmospheric Observation Data (2013) Research Institute for Sustainable Humanosphere. Kyoto University, http://database.rish.kyoto-u.ac.jp/arch/ jmadata/gpv-original.html. Accessed 6 July 2014

Goff J, Dudley WC, de Maintenon MJ, Cain G, Coney JP (2006) The largest local tsunami in 20th century Hawaii. Mar Geol 226:65-79

Goto K, Okada K, Imamura F (2009) Characteristics and hydrodynamics of boulders transported by storm waves at Kudaka Islands, Japan. Mar Geol 262:14-24

Goto K, Kawana T, Imamura F (2010a) Historical and geological evidence of boulders deposited by tsunamis, southern Ryukyu Islands, Japan. Earth-Sci Rev 102:77-99, doi:10.1016/j.earscirev.2010.06.005

Goto K, Miyagi K, Kawamata H, Imamura F (2010b) Discrimination of boulders deposited by tsunamis and storm waves at Ishigaki Island, Japan. Mar Geol 269:34-45

Harmelin-Vivien ML, Laboute P (1986) Catastrophic impact of hurricanes on atoll outer reef slopes in the Tuamotu (French Polynesia). Coral Reefs 5:55-62

Hirt C, Nichols BD (1981) Volume of fluid (VOF) method for dynamics of boundaries. J Comput Phys 39:201-225

Hsu Y-J, Ando M, Yu S-B, Simons M (2012) The potential for a great earthquake along the southernmost Ryukyu subduction zone. Geophys Res Lett 39, L14302, doi:10.1029/2012GL052764

Inoue S, Kayane H, Matta N, Chen WS, Ikeda Y (2011) Holocene uplifted coral reefs in Lanyu and Lutao Islands to the southeast of Taiwan. Coral Reefs 30:581-592

Jiang W-D, Chang H-K, Liou J-C, Chen W-W, Ho L-S (2011) Investigation of long-term wave statistics and design wave for main harbors of Taiwan (2/4). Report of Institute of Transportation, No. 100-52-7537 (in Chinese with English abstract)

Kawana T, Nakata T (1994) Timing of late Holocene tsunamis originated around the southern Ryukyu Islands, Japan, deduced from coralline tsunami deposits. J Geogr Jpn 103:352-376 (in Japanese)

Kunkel CM, Hallberg RW, Oppenheimer M (2006) Coral reefs reduce tsunami impact in model simulations. Geophys Res Lett 33, L23612, doi:10.1029/ 2006GL027892

Lau AYA, Switzer AD, Dominey-Howes D, Aitchison JC, Zong Y (2010) Written records of historical tsunamis in the northeastern South China Sea - challenges associated with developing a new integrated database. Nat Hazards Earth Syst Sci 10:1793-1806

Ma KF, Lee MF (1997) Simulation of historical tsunamis in the Taiwan region. Terr Atmos Ocean Sci 8:13-30

Mak S, Chan LS (2007) Historical tsunamis in South China. Nat Hazards 43:147-164, doi:10.1007/s1 1069-007-9113-6

Mastronuzzi G, Pignatelli C (2012) The boulder berm of Punta Saguerra (Taranto, Italy): a morphological imprint of the Rossano Calabro tsunami of April 24, 1836? Earth Planets Space 64:829-842, doi:10.5047/eps.2011.08.018
Matta N, Ota Y, Ando M, Nishizawa Y, Haraguchi T, Switzer A, Lin CH (2010) Possible evidence for paleotsunami at Chenggong Town, east coast of Taiwan. In: Abstracts of the Western Pacific geophysical meeting. U33B-237, Taipei

Matta N, Ota Y, Chen W-S, Nishikawa Y, Ando M, Chung L-H (2013) Findings of probable tsunami boulders on Jiupeng coast in southeastern Taiwan. Terr Atmos Ocean Sci 24:159-163

Ministry of the Interior (2004) Administration district map of Lanyu, Taitung (ISBN:9860012229). Ministry of the Interior, Taiwan

Nakamura M (2009) Fault model of the 1771 Yaeyama earthquake along the Ryukyu Trench estimated from the devastating tsunami. Geophys Res Lett 36, L19307, doi:10.1029/2009GL039730

Nandasena NAK, Paris R, Tanaka N (2011) Reassessment of hydrodynamic equations: minimum flow velocity to initiate boulder transport by high energy events (storms, tsunamis). Mar Geol 281:70-84

Nezu I (1995) Hydraulics and hydrodynamics. ISBN 978-4254261356. Asakura Publishing, Tokyo (in Japanese)

Nott J (2003) Waves, coastal boulders and the importance of the pre-transport setting. Earth Planet Sci Lett 210:269-276

Ota Y (2013) Finding of paleotsunami deposits in the east coast of Taiwan. In: Abstracts of the Western Pacific sedimentology meeting. 2013WPSM-S1.1-O6, Taoyuan

Richmond BM, Watt S, Buckley M, Jaffe BE, Gelfenbaum G, Morton RA (2011) Recent storm and tsunami coarse-clast deposit characteristics, southeast Hawaii. Mar Geol 283:79-89

Sakakiyama T, Imai S (1996) Numerical simulation of wave overtopping at seawall covered by wave-dissipating concrete blocks. Proc Coast Eng JSCE 43:696-700 (in Japanese)

Shuttle Radar Topography Mission (2001) Jet Propulsion Laboratory, National Aeronautics and Space Administration., http://www2.jpl.nasa.gov/srtm/. Accessed 6 July 2014

Shyu JB, Sieh K, Chen YG (2005) Neotectonic architecture of Taiwan and its implications for future large earthquakes. J Geophys Res 110, doi:10.1029/ 2004JB003251

Simkin T, Fiske RS (1983) Krakatau, 1883: the volcanic eruption and its effects. Smithsonian Institution Press, Washington, D.C

Su C-H, Liaw C-T, Hsu J-C (2009) Special report of observation data of wave at Hualien harbor (1990 2008) (Volume I). Report of Institute of Transportation, No. 93-115-7118(1)(2) (in Chinese with English abstract)

Yang TF, Tie JL, Chen CH, Lee T, Punonbayan RS (1995) Fission-track dating of volcanic on the northern part of the Taiwan-Luzon arc: eruption ages and evidence for crustal contamination. J Southeast Asian Earth Sci 11:81-93

Yang TF, Lee T, Chen CH, Cheng SN, Knittel U, Punonbayan RS, Rasdas AR (1996) A double island arc between Taiwan and Luzon: consequence of ridge subduction. Tectonophysics 258:85-101

Yu S-B, Chen H-Y, Kuo L-C (1997) Velocity field of GPS stations in the Taiwan area. Tectonophysics 274:41-59

\section{doi:10.1186/1880-5981-66-128}

Cite this article as: Nakamura et al:: Numerical simulations to account for boulder movements on Lanyu Island, Taiwan: tsunami or storm? Earth, Planets and Space 2014 66:128.

\section{Submit your manuscript to a SpringerOpen ${ }^{\circ}$ journal and benefit from:}

- Convenient online submission

- Rigorous peer review

- Immediate publication on acceptance

- Open access: articles freely available online

- High visibility within the field

- Retaining the copyright to your article

Submit your next manuscript at $\gg$ springeropen.com 